\title{
Poor blood pressure control and its associated factors among peoples living with Diabetes Mellitus in sub-Saharan Africa: A Systematic Review and Meta-analysis
}

Yonas Akalu ( $\square$ yonasakalu21@gmail.com )

University of Gondar https://orcid.org/0000-0002-0914-7768

Yigizie Yeshaw

University of Gondar

Getayeneh Antehunegn Tesema

University of Gondar

Sofonyas Abebaw Tiruneh

Debre Tabor University

Achamyeleh Birhanu Teshale

University of Gondar

Dessie Abebaw Angaw

University of Gondar

Misganew Gebrie

University of Gondar

Baye Dagnew

University of Gondar

Research

Keywords: Poor Blood Pressure Control, Hypertension, Diabetes Mellitus, Sub-Saharan Africa, Metaanalysis

Posted Date: December 7th, 2020

DOI: https://doi.org/10.21203/rs.3.rs-121901/v1

License: (9) (1) This work is licensed under a Creative Commons Attribution 4.0 International License. Read Full License 


\section{Abstract \\ Background}

Poor blood pressure control among people living with diabetes mellitus (DM) is one of the primary causes of cardiovascular complications and death in sub-Saharan Africa (SSA). However, there is paucity of evidence on the prevalence and associated factors of poor blood pressure control in SSA. Therefore, this review aimed to estimate the prevalence and its associated factors among people living with DM in SSA.

\section{Methods}

We systematically searched PubMed, African Journals online, Hinari, Google scholar and direct Google to access observational studies conducted in SSA. Microsoft excel spreadsheet was used to extract the data and then exported into STATA/MP version 16.0 for further analysis. Heterogeneity across studies was checked using Cochrane $\mathrm{Q}$ test statistic and $\mathrm{I}^{2}$ test and small study effect were checked using Funnel plot symmetry and Egger's statistical test at $5 \%$ significant level. A random-effects model was used to estimates the pooled prevalence of poor blood pressure control with a $95 \%$ confidence interval $(\mathrm{Cl})$.

\section{Results}

Of the 1,043 articles retrieved, 21 articles with an overall sample size of 6308 were eligible for the metaanalysis. After performing random-effects model, the pooled prevalence of poor blood pressure control was $69.8 \%$ (95\% Cl: $63.43,76.25 \%)$. Poor adherence to antihypertensive treatment $(\mathrm{OR}=1.7 ; 95 \% \mathrm{Cl}$ : $\left.1.03-2.80, \mathrm{I}^{2}=0.0 \%, \mathrm{p}=0.531\right)$ and overweight $\left(\mathrm{OR}=2.4,95 \% \mathrm{Cl}: 1.57-3.68, \mathrm{I}^{2}=0.00 \%, \mathrm{p}=0.47\right)$ were significantly associated with poor blood pressure control.

\section{Conclusions}

Only one third of diabetic patients in SSA had achieved target blood pressure. Hence, there is an urgent need for initiatives to improve and control hypertension, and preventive measures should concentrate on modifiable risk factors.

\section{Systematic Review registrations:}

The review protocol has been registered in PROSPERO with protocol number of CRD42020187901.

\section{Background}


Hypertension is the worldwide leading cause of cardiovascular diseases (CVD) and deaths (1), and accounts for around 7.5 million yearly deaths (2). Globally, an estimated 1.13 billion people are hypertensive, most (two-thirds) living in low- and middle-income countries (3). The highest prevalence of hypertension in the world is observed in SSA $(4,5)$. It tends to occur more commonly with diabetes and as many as $70-80 \%$ of diabetic patients suffer from hypertension, which worsens and accelerate the progression of both micro-and macro vascular complications of diabetes and results in 7.2-fold increase in the risk of mortality (6-9). Moreover, type 2 diabetes mellitus (T2DM) patients with hypertension have a two to four-fold greater risk of developing cardiovascular sequelae than age-matched normotensive type 2 diabetic controls (10).

Therefore, it is imperative to control cardiovascular disease (CVD) risk and mortality in diabetes patients and the most effective and powerful intervention to reduce it is controlling blood pressure by integrated use of life style modification and appropriate regimen and dose of anti-hypertensive medications $(11,12)$. The benefits of tight BP control in patients with diabetes exceed the benefits of tight glycemic control and extend to the prevention of macrovascular and microvascular complications $(13,14)$. Many randomized controlled trials and the United Kingdom Prospective Diabetes Study (UKPDS) showed that strict BP control in patients with hypertension and diabetes reduces the risk of stroke, coronary heart disease, congestive heart failure and other CVD, macrovascular and microvascular complications, and death (13, $15,16)$.

A meta-analysis has revealed that a $10 \mathrm{~mm} \mathrm{Hg}$ reduction in systolic blood pressure reduced the risk of major cardiovascular disease events by $20 \%$, coronary heart disease by $17 \%$, stroke by $27 \%$, heart failure by $28 \%$, and all-cause mortality by $13 \%$ (17). Lowering of blood pressure to treatment targets is therefore, a priority in individuals with diabetes to prevent complications (18-20). Even though different guidelines differ in their recommendations on BP targets in diabetic patients (21), many guideline committees had recommended that in patients with DM and hypertension, the target systolic and diastolic BP should be below 130 and $80 \mathrm{~mm} \mathrm{Hg}$, respectively $(6,21,22)$. However, most hypertensive diabetic patients fail to meet the recommended BP target. A study in USA by Andros et al. reported that poor blood pressure control among individuals with diabetes was still high and remains a major public health concern causing economic burden (23). In a longitudinal cohort study of 30,228 diabetic patients, only 43 and $30 \%$ of European American and African American diabetic hypertensive patients, respectively, demonstrated a target blood pressure of $130 / 80 \mathrm{mmHg}(24)$. In SSA rates of BP control range between 11 and $35 \%(25,26)$ and the cardiovascular complications in this region diabetic individuals are attributed to poor blood pressure control (27). A study carried out in six specialized diabetes care centers of six SSA showed an overall poor BP control in T2DM individuals despite adherence to guidelines (26). This implies the presence of other factors attributed to this poor BP control, including demographic, health literacy, and socio-economic characteristics (28). Moreover, overweight and noncompliance with antihypertensive drugs were strongly associated with uncontrolled hypertension $(29,30)$.

Even though extensive efforts to develop interventional BP control strategies to decrease risk of complications have been made in the past several decades, there is still significant rise in the risk of 
complications in diabetic patients with hypertension, and the control of BP is sub-optimal. To solve this problem and meet the blood pressure target, understanding of risk factors of blood pressure control particularly in SSA is important. Therefore this systematic review and meta-analysis aimed to determine the prevalence and associated factors of poor blood pressure control among people living with DM in SSA.

\section{Methods}

\section{Search strategies}

This systematic review and meta-analysis followed the Preferred Reporting Items for Systematic Reviews and Meta-Analysis guidelines (S1 Table, PRISMA Checklist) (31). PubMed, African Journals online, Hinari, Google scholar, and direct Google search were used to access relevant studies for this review. Moreover, references list of eligible studies were retrieved to account for the missed studies in the database searching. All studies reporting proportion or prevalence of poor blood pressure control among people living with DM (either T1DM or T2DM) in SSA countries were the target of this review.

A search strategy was established for each database by combining MeSH (Medical Subject Heading) terms. Example of the search strategy for PubMed (search strategies for all data bases attached as supplementary file):

(("uncontrolled hypertension"[Title/Abstract]) OR ("Hypertension control") OR ("blood pressure control") OR ("management of hypertension") OR ("Treatment of Hypertension”)) AND (("Diabetes Mellitus") OR ("Type 2 diabetes mellitus") OR ("Type 1 diabetes mellitus") OR ("Diabetes")) AND ( (Angola) OR (Benin) OR (Botswana) OR (Burkina Faso) OR (Burundi) OR (Cameroon) OR (Cape Verde) OR (Central African Republic) OR (Chad) OR (Comoros) OR (Congo) OR (Ivory Coast) OR (Democratic Republic of the Congo) OR (Djibouti) OR (Equatorial Guinea) OR (Eritrea) OR (Ethiopia) OR (Gabon) OR (Gambia) OR (Ghana) OR (Guinea) OR (Guinea-Bissau) OR (Kenya) OR (Lesotho) OR (Liberia) OR (Madagascar) OR (Malawi) OR (Mali) OR (Mauritania) OR (Mauritius) OR (Mayotte) OR (Mozambique) OR (Namibia) OR (Nigeria) OR (Reunion) OR (Rwanda) OR (Saint Helena) OR (Sao tome) OR (Senegal) OR (Seychelles) OR (Sierra Leone) OR (Somalia) OR (South Africa) OR (South Sudan) OR(Niger) OR (Swaziland) OR (Togo) OR (Uganda) OR (Tanzania)OR (Zambia) OR (Zimbabwe)).

\section{Eligibility criteria}

We used CoCoPop (Condition, Context, and Population) approach for prevalence studies to declare inclusion and exclusion criteria.

\section{Inclusion criteria and exclusion criteria}


We included all studies conducted in SSA countries, written in English language, published as of August 01, 2020 and reported prevalence and/or associated factors of poor blood pressure control among people living with type 1 or type 2 diabetes. All included studies were published. Studies which did not report prevalence of poor blood pressure control, case-reports, case-series, letters to the editors, and studies conducted on specific population were also excluded.

\section{Study selection}

All studies retrieved using different electronic databases were exported into endnote version X7. After excluding duplicated articles, titles of all articles were screened and abstracts and their full-texts were independently reviewed by two authors (YA and SAT). Disagreement between reviewers was resolved by further discussion and other reviewers (DAA and MG)

\section{Quality assessment}

The quality of included studies were assessed using the validated modified version of a quality assessment tool for prevalence studies (32). Two reviewers (BD and GAT) independently assessed the quality of the included studies and discrepancy in quality appraisal between the two authors was synchronized by the third reviewer (SAT). The quality assessment tool has 9 risk of bias items which has a maximum score of "9" and minimum score of "0". Ranking of risk of bias is labeled as low risk (0-3), moderate risk (4-6), and high risk (7-9) (32).

\section{Data extraction and management}

Findings on the prevalence and associated factors of poor blood pressure control among diabetic patients from each study were summarized by two authors (YA \& YY) using the data extraction format which was prepared with the assistance of the Joanna Briggs Institute (JBI) data extraction tool for prevalence studies and the extracted data were compared between the two authors (YA and YY). Discrepancies were resolved by consensus after discussion. For each study; name of the first author, year of publication, study design, sample size, blood pressure cut point used (to define poor blood pressure control), the prevalence of poor blood pressure control or number of cases with poor blood pressure control, and associated factor (sex, BMI, adherence) estimates (Odds ratio or the cases in each cell) with their standard error were extracted.

\section{Outcome measurement}

Outcome variable of this study was poor blood pressure control among peoples living with diabetes mellitus. In the primary studies, the outcome variable was defined using different blood pressure cut points. Included studies defined poor blood pressure control in diabetes as; 1: systolic blood pressure $(\mathrm{SBP}) \geq 140 \mathrm{mmHg}$ and /or a diastolic blood pressure (DBP) $\geq 90 \mathrm{mmHg} ; 2$ : SBP $\geq 140 \mathrm{mmHg}$ and / or a $\mathrm{DBP} \geq 80 \mathrm{mmHg}$, and $3: \mathrm{SBP} \geq 130 \mathrm{mmHg}$ and /or DBP $\geq 80$. The latest BP cut point to define poor blood pressure control is SBP $\geq 130 \mathrm{mmHg}$ and /or DBP $\geq 80$ in DM patients (33-35). 


\section{Statistical analysis}

The extracted data in the Microsoft excel were exported into STATA version 16.0 software for further analysis. The pooled estimate of poor blood pressure control prevalence and its associated factors were determined by the random-effects model using DerSimonian-Laird weight (36). Statistical heterogeneity was checked by Cochrane Q-test and $\mathrm{I}^{2}$ statistics (37). To minimize the variance of point estimates between primary studies subgroup analysis was carried out by BP cut point used to define poor BP control, year of publication, income level, type of DM, and sample size. Besides, sensitivity analysis was also conducted to determine the effect of single studies on the pooled estimate. Univariable metaregression was conducted by publication year, mean age of the respondent from primary studies, sample size and income level using random-effects model.

Publication bias (small study effect) was checked using funnel plot and statistically by Egger's test (38). Odds ratio(OR) and $95 \%$ confidence interval was used to identify factors associated with poor blood pressure control in people living with DM.

\section{Systematic Review registration}

The review protocol has been registered in PROSPERO with protocol number of CRD42020187901, URL: https://www.crd.york.ac.uk/PROSPERO/\#myprospero

\section{Results}

\section{Description of included studies}

We retrieved 1,043 records of journal articles in the electronic database search and 456 duplicates were removed. After scrupulous review of the titles and abstracts, we excluded 561 articles. Five articles were excluded in the full-text review because of difference in population under study (28), full text not found $(39,40)$, and reviews $(21,41)$. We used full-text copies of 21 records for further review with an overall sample size of 6,308 (Figure 1).

Of the 21 studies, 5 were from South Africa (42-46), 5 from Ethiopia (11, 47-50), 3 from Kenya (51-53), 2 from Tanzania $(54,55), 2$ from Nigeria $(56,57)$, and 1 from Cameron (58), Uganda (59), Botswana (60), and Ghana (61). All studies were institution based cross-sectional studies. To define poor blood pressure control, BP cut point of $\geq 140 / 90$ was used by 11 studies $(11,43,47,48,50,53,62-66), \geq 140 / 80$ by 3 studies $(45,59,67)$ and $\geq 130 / 80$ by 7 studies $(44,52,54-56,58)$ (Table 1$)$.

Table 1: Characteristics of the included studies and prevalence of poor blood pressure in individual studies 


\begin{tabular}{|c|c|c|c|c|c|c|c|}
\hline S.no & Author & $\begin{array}{l}\text { Publication } \\
\text { Year }\end{array}$ & Country & $\begin{array}{l}\text { Sample } \\
\text { size }\end{array}$ & $\begin{array}{l}\text { BP cut } \\
\text { point } \\
\text { used }\end{array}$ & $\begin{array}{l}\text { Prevalence } \\
\text { of Poor BP } \\
\text { control }\end{array}$ & $\begin{array}{l}\text { Quality } \\
\text { score }\end{array}$ \\
\hline 1 & $\begin{array}{l}\text { Simeon Pierre } \\
\text { et.al (58) }\end{array}$ & 2007 & Cameroon & 210 & $130 / 80$ & 89.8 & $\begin{array}{l}2 \text { (low } \\
\text { risk) }\end{array}$ \\
\hline 2 & Akalu et.al (48) & 2020 & Ethiopia & 378 & $140 / 90$ & 74.4 & $\begin{array}{l}2 \text { (low } \\
\text { risk) }\end{array}$ \\
\hline 3 & $\begin{array}{l}\text { Hailu A et. al. } \\
\text { (67) }\end{array}$ & 2017 & Ethiopia & 484 & $140 / 80$ & 63.6 & $\begin{array}{l}1 \text { (low } \\
\text { risk) }\end{array}$ \\
\hline 4 & $\begin{array}{l}\text { Anakwue RC et } \\
\text { a (56) }\end{array}$ & 2012 & Nigeria & 420 & $130 / 80$ & 88 & $\begin{array}{l}\text { O(low } \\
\text { risk) }\end{array}$ \\
\hline 5 & $\begin{array}{l}\text { E. O. Okoro et al } \\
\text { (62) }\end{array}$ & 2004 & Nigeria & 115 & $140 / 90$ & 89 & $\begin{array}{l}3 \text { (low } \\
\text { risk) }\end{array}$ \\
\hline 6 & $\begin{array}{l}\text { Y Pinchevsky e } \\
\text { al (44) }\end{array}$ & 2013 & $\begin{array}{l}\text { South } \\
\text { Africa }\end{array}$ & 666 & $130 / 80$ & 54.2 & $\begin{array}{l}\text { O(low } \\
\text { risk) }\end{array}$ \\
\hline 7 & $\begin{array}{l}\text { AM Klisiewicz et } \\
\text { al (42) }\end{array}$ & 2009 & $\begin{array}{l}\text { South } \\
\text { Africa }\end{array}$ & 150 & $130 / 80$ & 82 & $\begin{array}{l}2 \text { (low } \\
\text { risk) }\end{array}$ \\
\hline 8 & $\begin{array}{l}\text { Yacob } \\
\text { Pinchevsky et al } \\
\text { (45) }\end{array}$ & 2016 & $\begin{array}{l}\text { South } \\
\text { Africa }\end{array}$ & 261 & $140 / 80$ & 58 & $\begin{array}{l}3 \text { (low } \\
\text { risk) }\end{array}$ \\
\hline 9 & $\begin{array}{l}\text { N.S. Levitt et al } \\
\text { (43) }\end{array}$ & 1997 & $\begin{array}{l}\text { South } \\
\text { Africa }\end{array}$ & 300 & $140 / 90$ & 61.5 & $\begin{array}{l}2 \text { (low } \\
\text { risk) }\end{array}$ \\
\hline 10 & $\begin{array}{l}\text { Mwita JC et al } \\
\text { (54) }\end{array}$ & 2012 & Tanzania & 150 & $130 / 80$ & 66 & $\begin{array}{l}2 \text { (low } \\
\text { risk) }\end{array}$ \\
\hline 11 & $\begin{array}{l}\text { Kibirige et al. } \\
\text { (59) }\end{array}$ & 2014 & Uganda & 250 & $140 / 80$ & 44 & $\begin{array}{l}2 \text { (low } \\
\text { risk) }\end{array}$ \\
\hline 12 & $\begin{array}{l}\text { Sintayehu } \\
\text { Muleta et al (11) }\end{array}$ & 2017 & Ethiopia & 131 & $140 / 90$ & 56.5 & $\begin{array}{l}3 \text { (low } \\
\text { risk) }\end{array}$ \\
\hline 13 & $\begin{array}{l}\text { Julius Chacha } \\
\text { Mwita et al (66) }\end{array}$ & 2019 & Botswana & 500 & $140 / 90$ & 45.8 & $\begin{array}{l}1 \text { (low } \\
\text { risk) }\end{array}$ \\
\hline 14 & $\begin{array}{l}\text { Tariku Shimels } \\
\text { et al (50) }\end{array}$ & 2018 & Ethiopia & 361 & $140 / 90$ & 80.6 & $\begin{array}{l}\text { 2(low } \\
\text { risk) }\end{array}$ \\
\hline 15 & $\begin{array}{l}\text { Emmanuel M } \\
\text { Mwengi et al } \\
\text { (53) }\end{array}$ & 2019 & Kenya & 237 & $140 / 90$ & 69.2 & $\begin{array}{l}2 \text { (low } \\
\text { risk) }\end{array}$ \\
\hline 16 & $\begin{array}{l}\text { B. W. NDEGE et } \\
\text { al (52) }\end{array}$ & 2014 & Kenya & 218 & $130 / 80$ & 79 & $\begin{array}{l}2 \text { (low } \\
\text { risk) }\end{array}$ \\
\hline 17 & $\begin{array}{l}\text { Oladele Vincent } \\
\text { A. et al (65) }\end{array}$ & 2016 & $\begin{array}{l}\text { South } \\
\text { Africa }\end{array}$ & 265 & $140 / 90$ & 75.5 & $\begin{array}{l}3 \text { (low } \\
\text { risk) }\end{array}$ \\
\hline 18 & Semvua B1. & 2017 & Tanzania & 295 & $130 / 80$ & 84.5 & 2(low \\
\hline
\end{tabular}




\begin{tabular}{|c|c|c|c|c|c|c|c|}
\hline 19 & $\begin{array}{l}\text { Hailu Abera et al } \\
(47)\end{array}$ & 2016 & Ethiopia & 382 & $140 / 90$ & 85 & $\begin{array}{l}2 \text { (low } \\
\text { risk) }\end{array}$ \\
\hline 20 & $\begin{array}{l}\text { Mercy W. } \\
\text { Kimando1(64) }\end{array}$ & 2017 & Kenya & 385 & $140 / 90$ & 76.6 & $\begin{array}{l}2 \text { (low } \\
\text { risk) }\end{array}$ \\
\hline 21 & $\begin{array}{l}\text { James Osei- } \\
\text { Yeboah et al(63) }\end{array}$ & 2018 & Ghana & 150 & $140 / 90$ & 41.33 & $\begin{array}{l}3 \text { (low } \\
\text { risk) }\end{array}$ \\
\hline
\end{tabular}

\section{Pooled estimate of Poor Blood Pressure control among people living with DM in Sub-Saharan Africa}

The pooled prevalence of poor blood pressure control in 21 studies in sub-Saharan Africa was $69.8 \%$ (95\% Cl: $63.43,76.25 \%)$ and considerable heterogeneity was observed among studies $(12=97.3 \%$, $\mathrm{p}<0.001$ ) (Figure 2). The funnel plot shows symmetric distribution and the egger's test was not significant (estimated bias coefficient $=10.5$ with a standard error of 3.4 , and $p=0.180$ ), indicating no publication bias (Figure 3).

\section{Handling Heterogeneity}

The extent of heterogeneity among the included studies was high in the random-effects model pooled estimate. To handle this, sensitivity, subgroup and, meta-regression analyses were performed. In the sensitivity analysis, no influential study was found (Figure 4). We further did and report estimates from a sub group analysis considering other possible sources of variations including the cut point used to diagnosis poor BP control, type of DM, sample size, income, and year of publication. However, heterogeneity was not handled. A pooled prevalence from sub-group analysis showed, studies which used BP cut point of 130/80 mmHg systolic and diastolic blood pressure, respectively, had the highest prevalence of poor BP control (77.7\%) (Supplementary figure (S.Figure 1)), and the least pooled prevalence (55.3\%) was observed in the subgroup of studies those used $140 / 80 \mathrm{mmHg}$ as a BP cut point. Pooled prevalence of poor BP control was higher (71\%) in studies whose study population was both (type 1 and/or 2) types of DM than studies with study population of type 2 DM only (68.8\%) (S.Figure ). Higher pooled prevalence of poor blood pressure control (70.0\%) was found in studies with sample greater than or equal to 296 than the counter parts (S.Figure 3). Studies published from 2005-2012 had the highest pooled prevalence of poor blood pressure control (82.0\%) (S. Figure 4). Sub group analysis by income was also done and the highest pooled prevalence was found in lower middle income SSA countries (Ghana, Nigeria, Cameron) (77.3\%) followed by low income SSA countries (Ethiopia, Kenya, Uganda, Tanzania) (71.1\%) (S.Figure 5) (Table 2).

Table 2 Subgroup analysis of pooled prevalence of poor BP control among diabetic population in subSaharan Africa countries, $2020(n=21)$ 


\begin{tabular}{|c|c|c|c|c|c|}
\hline \multicolumn{2}{|c|}{ Subgroup analysis by } & $\begin{array}{l}\text { Included } \\
\text { studies }\end{array}$ & \multicolumn{2}{|l|}{$\begin{array}{l}\text { Sample } \\
\text { size }\end{array}$} & $\begin{array}{l}\text { Heterogeneity } \\
\left(I^{2}, p \text {-value }\right)\end{array}$ \\
\hline \multirow{3}{*}{$\begin{array}{l}\text { BP cut point } \\
\text { used }\end{array}$} & $130 / 80$ & 7 & 2,525 & $\begin{array}{l}77.7 \% \text { (66.92, } \\
88.39)\end{array}$ & $\begin{array}{l}97.5 \% \\
<0.001\end{array}$ \\
\hline & $140 / 80$ & 3 & 995 & $\begin{array}{l}55.3 \% \\
(43.92,66.71)\end{array}$ & $\begin{array}{l}92.4 \% \\
<0.001\end{array}$ \\
\hline & $140 / 90$ & 11 & 2788 & $\begin{array}{l}68.8 \%(60.21, \\
77.47)\end{array}$ & $97.3 \%,<0.001$ \\
\hline \multirow[t]{2}{*}{ Type of DM } & Type 2 DM & 11 & 3,754 & $\begin{array}{l}68.8 \% \\
(59.49,78.02)\end{array}$ & $\begin{array}{l}97.3 \% \\
<0.001\end{array}$ \\
\hline & $\begin{array}{l}\text { Both Type } 1 \text { and } \\
2\end{array}$ & 10 & 2554 & $\begin{array}{l}71 \%(61.83 \\
80.24)\end{array}$ & $\begin{array}{l}96.9 \% \\
<0.001\end{array}$ \\
\hline \multirow[t]{2}{*}{ Sample size } & $\leq 296$ & 12 & 2432 & $\begin{array}{l}69.7 \%(60.74 \\
70.61)\end{array}$ & $\begin{array}{l}96.6 \% \\
<0.001\end{array}$ \\
\hline & $>296$ & 9 & 3876 & $\begin{array}{l}70.0 \% \text { (60.19, } \\
79.88)\end{array}$ & $\begin{array}{l}98.1 \% \\
<0.001\end{array}$ \\
\hline \multirow[t]{3}{*}{$\begin{array}{l}\text { Publication } \\
\text { Year }\end{array}$} & 1997-2004 & 2 & 415 & $\begin{array}{l}\text { 75.2\%(48.68, } \\
101.7)\end{array}$ & $\begin{array}{l}97.7 \% \\
<0.001\end{array}$ \\
\hline & 2005-2012 & 4 & 930 & $\begin{array}{l}82.3 \% \text { (74.04, } \\
90.01)\end{array}$ & $\begin{array}{l}90.8 \% \\
<0.001\end{array}$ \\
\hline & 2013-2020 & 15 & 4,963 & $\begin{array}{l}66.0 \%(58.59 \\
73.44)\end{array}$ & $\begin{array}{l}97.2 \% \\
<0.001\end{array}$ \\
\hline \multirow[t]{3}{*}{ Income level } & Low income & 11 & 3271 & $\begin{array}{l}71.1 \%(64.35 \\
77.82)\end{array}$ & $\begin{array}{l}95.3 \% \\
<0.001\end{array}$ \\
\hline & $\begin{array}{l}\text { Lower middle } \\
\text { income }\end{array}$ & 4 & 895 & $\begin{array}{l}\text { 77.3\%(61.81, } \\
92.77)\end{array}$ & $\begin{array}{l}97.7 \% \\
<0.001\end{array}$ \\
\hline & $\begin{array}{l}\text { Upper middle } \\
\text { income }\end{array}$ & 6 & 2142 & $\begin{array}{l}\text { 62.7(52.15, } \\
73.32)\end{array}$ & $\begin{array}{l}96.3 \% \\
<0.001\end{array}$ \\
\hline
\end{tabular}

\section{Meta-regression}

To handle heterogeneity, we further fitted meta-regression on the aggregated study level variables using the random effects model. The univariable meta-regression analysis revealed that mean age, publication year, sample size and income level were not significantly associated with poor blood pressure control (Table 3).

Table 3: Univariable meta-regression analysis results for the prevalence of poor blood pressure control among diabetics in sub-Saharan Africa 


\begin{tabular}{|llll|}
\hline & \multicolumn{3}{c|}{ Standard error } \\
\hline Study level variables & Adjusted $\mathrm{R}^{2}$ & & Coefficients $(95 \% \mathrm{Cl})$ \\
\hline Mean age & 0.00 & 0.94 & $0.35(-1.49-2.19)$ \\
\hline Publication year & 0.00 & 0.60 & $-0.62(-1.80,0.54)$ \\
\hline Sample size & 4.40 & 0.02 & $-0.02(-0.06,0.03)$ \\
\hline Income level & 17.72 & 3.38 & $-4.56(-11.18,2.06)$ \\
\hline
\end{tabular}

Factors associated with poor blood pressure control among people living with diabetes mellitus in subSahara Africa

In the random effect model of meta-analysis of identified associated factors, the pooled effect of four studies $(11,50,55,65)$ showed, poor adherence to antihypertensive treatments (POR $=1.7 ; 95 \% \mathrm{Cl}: 1.03$, $2.80, l^{2}=0.0 \%, p=0.531$ ) was significantly associated with poor blood pressure control among peoples living with diabetes mellitus (Figure 5). The pooled effect of other three studies $(52,53,55)$ also showed that body mass index (BMI) of $\geq 25 \mathrm{~kg} / \mathrm{m}^{2}$ (POR $\left.=2.4,95 \% \mathrm{Cl}: 1.57,3.68\right), \mathrm{I}^{2}=0.00 \%, p=0.47$ ) was significantly associated with poor blood pressure control (Figure 06). On the other hand the pooled effect of eight studies $(11,50,52,53,55,64-66)$ showed that sex (POR=0.7, 95\% $\mathrm{Cl}, 0.49-1.12, \mathrm{I}^{2}=74.1 \%$, $p=0.001$ ) was not significantly associated with poor blood pressure control (Figure 07 ). The odds of poor blood pressure control among diabetic peoples with poor adherence to antihypertensive treatment was 1.7 times higher than the counter parts. Body mass index of $\geq 25 \mathrm{~kg} / \mathrm{m}^{2}$ was associated with a 2.4 times more likelihood of having poor blood pressure control (Table 4).

Table 4: Summary of the pooled effects of factors associated with poor blood pressure control among diabetics in sub-Saharan countries

\begin{tabular}{|c|c|c|c|c|c|c|}
\hline Variables & & $\begin{array}{l}\text { OR }(95 \% \\
\mathrm{Cl})\end{array}$ & $\begin{array}{l}\text { Heterogeneity } \\
\left(I^{2}, \text { P-value }\right)\end{array}$ & $\begin{array}{l}\text { Egger's } \\
\text { P-value }\end{array}$ & $\begin{array}{l}\text { Total } \\
\text { studies }\end{array}$ & $\begin{array}{l}\text { Sample } \\
\text { size }\end{array}$ \\
\hline \multirow[t]{2}{*}{ Sex } & Male & 1 & & & & \\
\hline & Female & $\begin{array}{l}0.7(0.49- \\
1.12)\end{array}$ & $\begin{array}{l}74.1 \% \\
<0.001\end{array}$ & 0.16 & 9 & 2,619 \\
\hline \multirow[t]{2}{*}{$\begin{array}{l}\text { Poor adherence to } \\
\text { antihypertensive treatments }\end{array}$} & Yes & $\begin{array}{l}\text { 1.7(1.03, } \\
2.80) *\end{array}$ & $0.0 \%, \quad<0.53$ & 0.42 & 4 & 1,052 \\
\hline & No & 1 & & & & \\
\hline \multirow[t]{2}{*}{ BMI $\left(\mathrm{kg} / \mathrm{m}^{2}\right)$} & $<25$ & 1 & & & & \\
\hline & $\begin{array}{l}\geq 25 \\
\mathrm{~kg} / \mathrm{m}^{2}\end{array}$ & $\begin{array}{l}2.4(1.57 \\
3.68)^{\star}\end{array}$ & $0.0 \%, \quad<0.47$ & 0.632 & 3 & 750 \\
\hline
\end{tabular}


*Significant at $p<0.05$

\section{Discussion}

In peoples living with diabetes, the risk of developing CVD and life-threatening complications is determined by the degree of control of hypertension. However, the rate of control of hypertension is often inadequate and the cardiovascular complications in SSA diabetic individuals are attributed to poor blood pressure control $(14,27,68)$. This systematic review and meta-analysis estimated the pooled prevalence and associated factors of poor blood pressure control among peoples living with diabetes mellitus in subSaharan Africa.

The pooled prevalence of poor blood control in diabetes patients among 21 studies in SSA was $69.8 \%$ (95\% Cl: $63.43,76.25 \%)$. But due to the difference in blood pressure cut point used to diagnose poor BP control by these studies, subgroup analysis was done by BP cut point. Accordingly, the pooled prevalence of poor blood control among diabetes patients in seven SSA studies that use $130 / 80 \mathrm{mmHg}$ as cut point was $77.7 \%$ (95\% Cl: 66.92, 88.39) which is in line with a LEADER trail study among type 2 diabetes patients in 32 countries (74\%) (69), a large scale study in Malaysia (76.5\%) (70), and a systematic review and meta-analysis of 44 studies (88\%) that use the same BP cut point to diagnose poor blood pressure control (71). The high prevalence of poor BP control in people with diabetes might be due to different factors, like the likelihood that a more emphasis on glucose control and under emphasis of treatment for associated risk factors such as hypertension (71). In addition, inadequate access to follow-up care and prescription medications, inappropriate or ineffective treatments, poor adherence to prescription medication and lifestyle modifications or a combination of these factors may be responsible $(72,73)$. Low compliance is the main reason for poor control of blood pressure in SSA (74). This high prevalence of poor blood pressure control among diabetes suggests urgent need for initiatives to improve and control of hypertension.

However, the prevalence of poor BP control in this review is higher than the finding of a review of 16 studies (64.8\%) (75), a nationwide study in Korea (60.1\%) (76), a study in Malaysia (52.8\%) (77), and other large scale cohort studies (59.7\%) (78) and (60\%) (79). This inconsistency could be explained by the fact that patients in SSA countries have low socioeconomic status and poor wealth index that are attributed to the weak health systems resulting in poor access to medications and healthier life style (80, 81). They have low access to quality healthcare services, are more likely to have low healthier lifestyle and to be non-adherent to their medications due to barriers in accessing medical care, unaffordable health care costs, lack of transport money to visit the hospital and other reasons, leading to poor blood pressure control $(82,83)$. A great proportion of populations in SSA countries have no access to more than one blood pressure lowering drugs and, when they are available, they are not affordable (84). Poor dietary quality and practice such as, high saturated- and trans-fatty acid intake, and low fruit and vegetable consumption and physical inactivity are increasingly becoming prevalent in low and middle income countries (LMICs) $(81,85-87)$. The mean salt intake in most of the LMICs is also beyond the 
recommended maximum intake (88). These all factors might contribute to the higher prevalence of poor BP control in SSA.

On the contrary, the prevalence of poor BP control among peoples living with diabetes in this review is lower than the prevalence of poor blood pressure control in Spain (90.2\%) (89). This variation may possibly due to difference in; proportion of overweight and obesity, magnitude of co-morbidity, age of study participants, and patient, physician and sociocultural factors, which are hypothesized to have impact on BP control $(90,91)$.

On the other nine studies of this review which used BP cut point of 140/90, the pooled prevalence of poor blood pressure control was $70.0 \%$ (95\% Cl: $61.9 \%, 78.08)$. A similar study that uses the same BP cut point to diagnose poor blood pressure control in Saudi Arabia among 1178 diabetic reported a consistent finding (71.8\%) (92). In this systematic review and meta-analysis, the lowest pooled prevalence of poor blood pressure control (55.3\%) was found in three studies that uses BP cut point of 140/80. This finding is lower than any of the above prevalence reports, which is clearly due to the BP cut point used to diagnose poor BP control.

In this review, diabetes patients with poor adherence to antihypertensive medications were more likely to have poor blood pressure control. This finding is in agreement with existing literature showing higher prevalence of poor blood pressure control among patients with poor adherence $(70,76,93,94)$. This is due to the fact that adherence to antihypertensive therapies is a primary determinant of treatment success and poor medication adherence is the primary cause for poor control of BP (95). Poor adherence attenuates effectiveness of antihypertensive drugs. Moreover, it is noticeable that poorly adherent patients are less likely to undertake a healthier life style, contributing to poor BP control (94). Therefore, this review indicates the need of counseling and encouraging patients to adhere to antihypertensive medications, as adherence to antihypertensive medications is a key to achieving an optimal BP.

In the current review, BMI of $25 \mathrm{~kg} / \mathrm{m}^{2}$ or greater was associated with poor blood pressure control. Consistently, other studies reported that being obese is associated with poor blood pressure control ( 70 , $76,96-100)$. In obesity there is an increased production of leptin, a polypeptide produced from adipocyte which stimulate sympathetic activity leading to renal water retention, increased heart rate and peripheral vascular resistance, and finally worsening of hypertension (101). Besides, obesity decreases sensitivity of peripheral tissues to insulin (causing insulin resistance) resulting compensatory hyperinsulinemia. This increased insulin has a primary effect on activation of sympathetic nervous system, endothelial dysfunction, and failure of peripheral vasodilation (102). Insulin or leptin induced activation of sympathetic nervous system is also associated with tubular sodium reabsorption and volume expansion, and consequent increased blood pressure (103). Moreover, an increase in BMI results in increased renin and plasma angiotensin-converting enzyme activity, angiotensin level, and plasma aldosterone (104), thereby causing poor blood pressure control. 
Findings from the current review might be helpful for clinicians, programmers, and policymakers to design a strategy and take prompt interventions which would prevent complications and death due to uncontrolled hypertension in peoples living with diabetes and hypertension comorbidity.

\section{Limitations}

Though sensitivity, subgroup, and meta-regression analyses were conducted to minimize the effect of heterogeneity, the extent of heterogeneity among the included studies was high, which might be due to the difference in the study area, methodology, study period, blood pressure cut point used, and other unexplained variations. Use of different BP cut points by primary studies to define poor blood pressure control in DM patients was the other possible limitation of this review. Hence, clinicians and policymakers should consider these during the interpretations of results.

\section{Conclusion}

The pooled prevalence of poor blood pressure control among peoples with diabetes was high. Only one third of diabetic patients had achieved target blood pressure. This high prevalence of poor BP in hypertensive diabetic peoples highlights the urgency for primary health care re-engineering and an urgent need for initiatives to improve and control of hypertension. BMI of $25 \mathrm{~kg} / \mathrm{m}^{2}$ or greater and poor adherence to antihypertensive treatments were significantly associated with poor blood pressure control. Preventive measures should concentrate on overweight patients and patients with poor adherence to antihypertensive medications.

\section{Abbreviations}

BP: Blood Pressure; BMI: Body Mass Index; DBP: Diastolic Blood Pressure (DBP); DM: Diabetes Mellitus; LMICs: Low and Middle Income Countries; SBP: Systolic Blood Pressure; SSA: sub Saharan African Countries; T2DM: Type 2 Diabetes Mellitus

\section{Declarations}

\section{Ethics approval and consent to participate}

Not Applicable

\section{Consent for publication.}

Not applicable.

\section{Availability of data and materials}

All the materials and data are presented within the manuscript. 


\section{Competing interests}

All authors declared that there is no competing interest.

\section{Funding}

Not applicable.

\section{Authors' contribution}

YA, YY, GAT, BD: conceived the design; MG and SAT develop the search strategy;

YA, YY, GAT, DAA, ABT: searched, screened, and appraised the studies, and extract the data: SAT analyzed the data; GAT, YA, BD, ABT, MG: drafted the manuscript. All authors read and approved the final manuscript for publication.

\section{Acknowledgment}

Not applicable

\section{References}

1. WHO. Global health risks: mortality and burden of disease attributable to selected major risks: World Health Organization; 2009 [cited 202025 July ]. Available from:

https://apps.who.int/iris/handle/10665/44203

2. Rodgers A, Ezzati M, Vander Hoorn S, Lopez AD, Lin R-B, Murray CJ. Distribution of major health risks: findings from the Global Burden of Disease study. PLoS Med. 2004;1(1):e27.

3. WHO. Hypertension September13, 2019 [cited 20201 August 2020]. Available from: https://www.who.int/news-room/fact-sheets/detail/hypertension.

4. User S. IDF diabetes atlas-across the globe [Internet]. 2018.

5. Peck RN, Smart LR, Beier R, Liwa AC, Grosskurth H, Fitzgerald DW, et al. Difference in blood pressure response to ACE-Inhibitor monotherapy between black and white adults with arterial hypertension: a meta-analysis of 13 clinical trials. BMC nephrology. 2013;14(1):201.

6. Deedwania PC. Blood pressure control in diabetes mellitus: is lower always better, and how low should it go? : Am Heart Assoc; 2011.

7. De Boer IH, Bangalore S, Benetos A, Davis AM, Michos ED, Muntner P, et al. Diabetes and hypertension: a position statement by the American Diabetes Association. Diabetes care. 2017;40(9):1273-84.

8. Stratton I, Cull C, Adler A, Matthews D, Neil H, Holman R. Additive effects of glycaemia and blood pressure exposure on risk of complications in type 2 diabetes: a prospective observational study (UKPDS 75). Diabetologia. 2006;49(8):1761-9. 
9. Mills KT, Bundy JD, Kelly TN, Reed JE, Kearney PM, Reynolds K, et al. Global disparities of hypertension prevalence and control: a systematic analysis of population-based studies from 90 countries. Circulation. 2016;134(6):441-50.

10. Beckman JA, Creager MA, Libby P. Diabetes and atherosclerosis: epidemiology, pathophysiology, and management. Jama. 2002;287(19):2570-81.

11. Muleta S, Melaku T, Chelkeba L, Assefa D. Blood pressure control and its determinants among diabetes mellitus co-morbid hypertensive patients at Jimma University medical center, South West Ethiopia. Clinical hypertension. 2017;23(1):29.

12. Vargas-Uricoechea H, Cáceres-Acosta MF. Control of blood pressure and cardiovascular outcomes in type 2 diabetes. Open Medicine. 2018;13(1):304-23.

13. Group UPDS. Tight blood pressure control and risk of macrovascular and microvascular complications in type 2 diabetes: UKPDS 38. BMJ (Clinical research ed). 1998;317(7160):703-13.

14. Salanitro AH, Roumie CL. Blood pressure management in patients with diabetes. Clinical Diabetes. 2010;28(3):107-14.

15. Psaty BM, Lumley T, Furberg CD, Schellenbaum G, Pahor M, Alderman MH, et al. Health outcomes associated with various antihypertensive therapies used as first-line agents: a network metaanalysis. Jama. 2003;289(19):2534-44.

16. Chobanian A. National heart, lung, and blood institute; national high blood pressure education program coordinating committee. seventh report of the joint national committee on prevention, detection, evaluation, and treatment of high blood pressure. Hypertension (Dallas, Tex : 1979). 2003;42:1206-52.

17. Staessen JA, Wang J-G, Thijs L. Cardiovascular protection and blood pressure reduction: a metaanalysis. The Lancet. 2001;358(9290):1305-15.

18. Lopez-Jaramillo P, Lopez-Lopez J, Lopez-Lopez C, Rodriguez-Alvarez MI. The goal of blood pressure in the hypertensive patient with diabetes is defined: now the challenge is go from recommendations to practice. Diabetology \& metabolic syndrome. 2014;6(1):1-10.

19. Lastra G, Syed S, Kurukulasuriya LR, Manrique C, Sowers JR. Type 2 diabetes mellitus and hypertension: an update. Endocrinology and metabolism clinics of North America. 2014;43(1):10322.

20. Bahl VK, Jadhav UM, Thacker HP. Management of hypertension with the fixed combination of perindopril and amlodipine in daily clinical practice. American journal of cardiovascular drugs. 2009;9(3):135-42.

21. Grossman A, Grossman E. Blood pressure control in type 2 diabetic patients. Cardiovascular diabetology. 2017;16(1):3.

22. Chobanian A, Bakris G, Black H, Cushman W, Green L, Izzo J, et al. Joint National Committee on Prevention D, Joint National Committee on Prevention D, and Treatment of High Blood Pressure. National Heart, Lung, and Blood Institute, Committee NHBPEPC. Seventh report of the Joint National 
Committee on Prevention, Detection, Evaluation, and Treatment of High Blood Pressure Hypertension. 2003;42:1206-52.

23. Andros V, Egger A. Blood pressure goal attainment according to JNC 7 guidelines and utilization of antihypertensive drug therapy in MCO patients with type 1 or type 2 diabetes. Journal of Managed Care Pharmacy. 2006;12(4):303-9.

24. Cummings DM, Doherty L, Howard G, Howard VJ, Safford MM, Prince V, et al. Blood pressure control in diabetes: temporal progress yet persistent racial disparities: national results from the REasons for Geographic And Racial Differences in Stroke (REGARDS) study. Diabetes care. 2010;33(4):798-803.

25. Choukem SP, Kengne AP, Dehayem YM, Simo NL, Mbanya JC. Hypertension in people with diabetes in sub-Saharan Africa: revealing the hidden face of the iceberg. Diabetes research and clinical practice. 2007;77(2):293-9.

26. Joshi MD, Amayo EO. Cardiovascular risk factors in patients with type 2 diabetes mellitus in Kenya: levels of control attained at the Outpatient Diabetic Clinic of Kenyatta National Hospital, Nairobi. East African medical journal. 2006;83(7):405-6; author reply 6-7.

27. Sobngwi E, Mfeukeu-Kuate L, Kouam M, Tankeu AT. Short-term effects of perindopril-amlodipine vs perindopril-indapamide on blood pressure control in sub-Saharan type 2 diabetic individuals newly diagnosed for hypertension: A double-blinded randomized controlled trial. 2019;21(7):1002-8.

28. Sarfo FS, Mobula LM, Burnham G, Ansong D, Plange-Rhule J, Sarfo-Kantanka O, et al. Factors associated with uncontrolled blood pressure among Ghanaians: evidence from a multicenter hospital-based study. PloS one. 2018;13(3):e0193494.

29. Shea S, Misra D, Ehrlich MH, Field L, Francis CK. Predisposing factors for severe, uncontrolled hypertension in an inner-city minority population. The New England journal of medicine. 1992;327(11):776-81.

30. Adeniyi OV, Longo-Mbenza B, Ter Goon D. Female sex, poverty and globalization as determinants of obesity among rural South African type 2 diabetics: a cross-sectional study. BMC public health. 2015;15:298.

31. Liberati A, Altman DG, Tetzlaff J, Mulrow C, Gøtzsche PC, loannidis JP, et al. The PRISMA statement for reporting systematic reviews and meta-analyses of studies that evaluate health care interventions: explanation and elaboration. Journal of clinical epidemiology. 2009;62(10):e1-e34.

32. Hoy D, Brooks P, Woolf A, Blyth F, March L, Bain C, et al. Assessing risk of bias in prevalence studies: modification of an existing tool and evidence of interrater agreement. Journal of clinical epidemiology. 2012;65(9):934-9.

33. Guo F, He D, Zhang W, Walton RG. Trends in prevalence, awareness, management, and control of hypertension among United States adults, 1999 to 2010. Journal of the American College of Cardiology. 2012;60(7):599-606.

34. Mancia G, Fagard R, Narkiewicz K, Redon J, Zanchetti A, Böhm M, et al. 2013 ESH/ESC Practice guidelines for the management of arterial hypertension: ESH-ESC The Task Force for the 
management of arterial hypertension of the European Society of Hypertension (ESH) and of the European Society of Cardiology (ESC). Blood pressure. 2014;23(1):3-16.

35. Ogihara T, Kikuchi K, Matsuoka H, Fujita T, Higaki J, Horiuchi M, et al. The Japanese Society of Hypertension guidelines for the management of hypertension (JSH 2009). Hypertens Res. 2009;32(1):3-107.

36. DerSimonian R, Laird N. Meta-analysis in clinical trials. Controlled clinical trials. 1986;7(3):177-88.

37. Higgins J, Green S. Cochrane handbook for systematic reviews of interventions The Cochrane Collaboration., 2010. Chichester, England: John Wiley \& Sons. Google Scholar.

38. Egger M, Smith GD, Schneider M, Minder C. Bias in meta-analysis detected by a simple, graphical test. BMJ (Clinical research ed). 1997;315(7109):629-34.

39. Kolawole B, Adegbenro C, Ayoola Z, Opebiyi B. Diabetes mellitus related treatment goals: awareness and attainment in the Ife-ljesa zone of south-western Nigeria. African journal of medicine and medical sciences. 2005;34(4):389-94.

40. Otieno CF, Vaghela V, Mwendwa FW, Kayima JK, Ogola EN. Cardiovascular risk factors in patients with type 2 diabetes mellitus in Kenya: levels of control attained at the Outpatient Diabetic Clinic of Kenyatta National Hospital, Nairobi. East African medical journal. 2005;82(12 Suppl):S184-90.

41. Do DV, Wang X, Vedula SS, Marrone M, Sleilati G, Hawkins BS, et al. Blood pressure control for diabetic retinopathy. Cochrane Database of Systematic Reviews. 2015(1).

42. Klisiewicz A, Raal F. Sub-optimal management of type 2 diabetes mellitus-a local audit. Journal of Endocrinology, Metabolism and Diabetes of South Africa. 2009;14(1).

43. Levitt N, Bradshaw D, Zwarenstein M, Bawa A, Maphumolo S. Audit of public sector primary diabetes care in Cape Town, South Africa: high prevalence of complications, uncontrolled hyperglycaemia, and hypertension. Diabetic Medicine. 1997;14(12):1073-7.

44. Pinchevsky Y, Butkow W, Raal FJ, Chirwa T. The implementation of guidelines in a South African population with type 2 diabetes. Journal of Endocrinology, Metabolism and Diabetes of South Africa. 2013;18(3):154-8.

45. Pinchevsky Y, Shukla VJ, Butkow N, Chirwa T, Raal F. Multi-ethnic differences in HbA1c, blood pressure, and low-density-lipid cholesterol control among South Africans living with type 2 diabetes, after a 4-year follow-up. International journal of general medicine. 2016;9:419.

46. Adeniyi OV, Yogeswaran P, Longo-Mbenza B, Ter Goon D. Uncontrolled Hypertension and Its Determinants in Patients with Concomitant Type 2 Diabetes Mellitus (T2DM) in Rural South Africa. PloS one. 2016;11(3):e0150033.

47. Abera $\mathrm{H}$, Woldemichael $\mathrm{M}$. Pattern of antihypertensive therapy among diabetic hyperten-sive patients in zewditu memorial hospital, addis ababa. Diabetes. 2016;1:2.

48. Akalu Y, Belsti Y. Hypertension and Its Associated Factors Among Type 2 Diabetes Mellitus Patients at Debre Tabor General Hospital, Northwest Ethiopia. 2020;13:1621-31. 
49. Mulatu HA, Bayisa T, Berhe T, Woldeyes E. Pattern of antihypertensive treatment and blood pressure control among diabetic outpatients in Addis Ababa, Ethiopia. Journal of Diabetes \& Metabolism. 2017;8(4).

50. Shimels T, Abebaw M, Bilal Al, Tesfaye T. Treatment pattern and factors associated with blood pressure and fasting plasma glucose control among patients with type 2 diabetes mellitus in Police referral hospital in Ethiopia. Ethiopian journal of health sciences. 2018;28(4).

51. Kimando MW, Otieno FCF. Adequacy of control of cardiovascular risk factors in ambulatory patients with type 2 diabetes attending diabetes out-patients clinic at a county hospital, Kenya. 2017;17(1):73.

52. Ndege B, Diero L, Owiti M, Anjichi G, Sika A. Prevalence, treatment and control of hypertension among type 2 diabetic patients at Moi teaching and referral hospital, Eldoret, Kenya. East African medical journal. 2014;91(8):253-60.

53. Mwengi EM, Nyamu DG, Njogu PM, Karimi PN. Antihypertensive therapy and adequacy of blood pressure control among adult hypertensive diabetic patients with chronic kidney disease in a tertiary referral hospital. Hospital Practice. 2019;47(3):136-42.

54. Mwita JC, Mugusi F, Lwakatare J, Chiwanga F. Hypertension control and other cardiovascular risk factors among diabetic patients at Muhimbili National Hospital, Tanzania. East African journal of public health. 2013;10(1):337-42.

55. Kilonzo SB, Gunda DW, Bakshi FA, Kalokola F, Mayala HA, Dadi H. Control of hypertension among diabetic patients in a referral hospital in Tanzania: A cross-sectional study. Ethiopian journal of health sciences. 2017;27(5):473-80.

56. Anakwue R, Arodiwe E, Ofoegbu E. The prevalence and control of hypertension among patients with type 2 diabetes mellitus in Nigeria. International Journal of Medicine and Health Development. 2012;17:11-23.

57. Okoro EO, Oyejola BA. Inadequate control of blood pressure in Nigerians with diabetes. Ethnicity \& disease. 2004;14(1):82-6.

58. Choukem SP, Kengne AP, Dehayem YM, Simo NL, Mbanya JC. Hypertension in people with diabetes in sub-Saharan Africa: revealing the hidden face of the iceberg. Diabetes research and clinical practice. 2007;77(2):293-9.

59. Kibirige D, Atuhe D, Sebunya R, Mwebaze R. Suboptimal glycaemic and blood pressure control and screening for diabetic complications in adult ambulatory diabetic patients in Uganda: a retrospective study from a developing country. Journal of Diabetes \& Metabolic Disorders. 2014;13(1):40.

60. Mwita JC, Francis JM, Omech B, Botsile E, Oyewo A, Mokgwathi M, et al. Glycaemic, blood pressure and low-density lipoprotein-cholesterol control among patients with diabetes mellitus in a specialised clinic in Botswana: a cross-sectional study. BMJ open. 2019;9(7):e026807.

61. Osei-Yeboah J, Owiredu W, Norgbe G, Obirikorang C, Lokpo S, Ashigbi E, et al. Physical Activity Pattern and Its Association with Glycaemic and Blood Pressure Control among People Living with 
Diabetes (PLWD) In The Ho Municipality, Ghana. Ethiopian journal of health sciences. 2019;29(1):819-30.

62. Okoro E, Oyejola B. Inadequate control of blood pressure in Nigerians with diabetes. Ethnicity and Disease. 2004;14(1):82-6.

63. Osei-Yeboah J, Owiredu W, Norgbe G, Obirikorang C, Lokpo S, Ashigbi E, et al. Physical activity pattern and its association with glycaemic and blood pressure control among people living with diabetes (PLWD) in the Ho municipality, Ghana. Ethiopian journal of health sciences. 2019;29(1).

64. Kimando MW, Otieno FC, Ogola EN, Mutai K. Adequacy of control of cardiovascular risk factors in ambulatory patients with type 2 diabetes attending diabetes out-patients clinic at a county hospital, Kenya. BMC endocrine disorders. 2017;17(1):73.

65. Adeniyi OV, Yogeswaran P, Longo-Mbenza B, Goon DT. Uncontrolled hypertension and its determinants in patients with concomitant type 2 diabetes mellitus (T2DM) in rural South Africa. PloS one. 2016;11(3):e0150033.

66. Mwita JC, Francis JM, Omech B, Botsile E, Oyewo A, Mokgwathi M, et al. Glycaemic, blood pressure and low-density lipoprotein-cholesterol control among patients with diabetes mellitus in a specialised clinic in Botswana: a cross-sectional study. BMJ open. 2019;9(7):e026807.

67. Mulatu H, Bayisa T, Berhe T, Woldeyes E. Pattern of Antihypertensive Treatment and Blood Pressure Control among Diabetic Outpatients in Addis Ababa, Ethiopia. J Diabetes Metab 8: 738. doi: 10.4172/2155-6156.1000738 Page 2 of $4 \mathrm{~J}$ Diabetes Metab, an open access journal ISSN: 21556156 Volume 8• Issue 4 1000738 . Angiotensin converting enzyme inhibitor (ACEI) and calcium channel blocker (CCB) were the most frequently prescribed anti-hypertensive drug classes in. 2017;313(64.5):3.

68. Federation ID. Diabetes complications 2020 [updated 22/05/2020; cited 2020 september 03, 2020]. Available from: https://www.idf.org/aboutdiabetes/complications.html.

69. Petrie JR, Marso SP, Bain SC, Franek E, Jacob S, Masmiquel L, et al. LEADER-4: blood pressure control in patients with type 2 diabetes and high cardiovascular risk: baseline data from the LEADER randomized trial. Journal of hypertension. 2016;34(6):1140.

70. Chew BH, Mastura I, Shariff-Ghazali S, Lee PY, Cheong AT, Ahmad Z, et al. Determinants of uncontrolled hypertension in adult type 2 diabetes mellitus: an analysis of the Malaysian diabetes registry 2009. Cardiovascular diabetology. 2012;11(1):54.

71. McLean DL, Simpson SH, McAlister FA, Tsuyuki RT. Treatment and blood pressure control in 47,964 people with diabetes and hypertension: a systematic review of observational studies. Canadian Journal of Cardiology. 2006;22(10):855-60.

72. McAlister FA, Campbell NR, Zarnke K, Levine M, Graham ID. The management of hypertension in Canada: a review of current guidelines, their shortcomings and implications for the future. Cmaj. 2001;164(4):517-22.

73. Brown LC, Johnson JA, Majumdar SR, Tsuyuki RT, McAlister FA. Evidence of suboptimal management of cardiovascular risk in patients with type 2 diabetes mellitus and symptomatic 
atherosclerosis. Cmaj. 2004;171(10):1189-92.

74. Seedat Y. Why is control of hypertension in sub-Saharan Africa poor? Cardiovascular journal of Africa. 2015;26(4):193.

75. Pinchevsky Y, Butkow N, Chirwa T, Raal F. Glycaemic, blood pressure and cholesterol control in 25 629 diabetics. Cardiovascular journal of Africa. 2015;26(4):188.

76. Seo MH, Lee WJ, Park CY, Kim SR, Park JY, Yoon K-H, et al. Management of blood pressure in patients with type 2 diabetes mellitus: a nationwide survey in Korean. Diabetes \& metabolism journal. 2011;35(4):348-53.

77. Abougalambou SSI, Abougalambou AS. A study evaluating prevalence of hypertension and risk factors affecting on blood pressure control among type 2 diabetes patients attending teaching hospital in Malaysia. Diabetes \& Metabolic Syndrome: Clinical Research \& Reviews. 2013;7(2):83-6.

78. Greenberg JD, Tiwari A, Rajan M, Miller D, Natarajan S, Pogach L. Determinants of sustained uncontrolled blood pressure in a national cohort of persons with diabetes. American journal of hypertension. 2006;19(2):161-9.

79. Duggirala MK, Cuddihy RM, Cuddihy M-T, Naessens JM, Cha SS, Mandrekar JN, et al. Predictors of blood pressure control in patients with diabetes and hypertension seen in primary care clinics. American journal of hypertension. 2005;18(6):833-8.

80. Antignac M, Diop IB, Macquart de Terline D, Kramoh KE, Balde DM, Dzudie A, et al. Socioeconomic Status and Hypertension Control in Sub-Saharan Africa: The Multination EIGHT Study (Evaluation of Hypertension in Sub-Saharan Africa). Hypertension (Dallas, Tex : 1979). 2018;71(4):577-84.

81. Palafox B, McKee M, Balabanova D, AlHabib KF, Bahonar A, Ismail N, et al. Wealth and cardiovascular health: a cross-sectional study of wealth-related inequalities in the awareness, treatment and control of hypertension in high-, middle-and low-income countries. International journal for equity in health. 2016;15(1):199.

82. Nielsen J, Shrestha AD, Neupane D, Kallestrup P. Non-adherence to anti-hypertensive medication in low- and middle-income countries: a systematic review and meta-analysis of 92443 subjects. Journal of human hypertension. 2017;31(1):14-21.

83. Gudina EK, Amade ST, Tesfamichael FA, Ram R. Assessment of quality of care given to diabetic patients at Jimma University Specialized Hospital diabetes follow-up clinic, Jimma, Ethiopia. BMC endocrine disorders. 2011;11(1):19.

84. Attaei MW, Khatib R, McKee M, Lear S, Dagenais G, Igumbor EU, et al. Availability and affordability of blood pressure-lowering medicines and the effect on blood pressure control in high-income, middleincome, and low-income countries: an analysis of the PURE study data. The Lancet Public health. 2017;2(9):e411-e9.

85. Organization WH. Global health risks: mortality and burden of disease attributable to selected major risks: World Health Organization; 2009.

86. Elmadfa I, Kornsteiner M. Dietary fat intake-a global perspective. Annals of Nutrition and Metabolism. 2009;54(Suppl. 1):8-14. 
87. Popkin BM. Global nutrition dynamics: the world is shifting rapidly toward a diet linked with noncommunicable diseases-. The American journal of clinical nutrition. 2006;84(2):289-98.

88. Brown IJ, Tzoulaki I, Candeias V, Elliott P. Salt intakes around the world: implications for public health. International journal of epidemiology. 2009;38(3):791-813.

89. Alemán A, Hernández L, Galindo B, de la Sierra Iserte A, Claros M, Romanos G. Evaluation and control of hypertensive diabetics seen in Primary Care centres in Spain. BRAND II study. Atencion primaria. 2011;43(6):297-304.

90. Nishigaki N, Shimasaki Y, Yoshida T, Hasebe N. Physician and patient perspectives on hypertension management and factors associated with lifestyle modifications in Japan: results from an online survey. Hypertens Res. 2020;43(5):450-62.

91. Serour M, Alqhenaei H, Al-Saqabi S, Mustafa AR, Ben-Nakhi A. Cultural factors and patients' adherence to lifestyle measures. The British journal of general practice : the journal of the Royal College of General Practitioners. 2007;57(537):291-5.

92. Almalki ZS, Albassam AA, Alhejji NS, Alotaibi BS, Al-Oqayli LA, Ahmed NJ. Prevalence, risk factors, and management of uncontrolled hypertension among patients with diabetes: A hospital-based cross-sectional study. Primary care diabetes. 2020.

93. Jafar TH, Gandhi M, Jehan I, Naheed A, de Silva HA, Shahab H, et al. Determinants of uncontrolled hypertension in rural communities in South Asia-Bangladesh, Pakistan, and Sri Lanka. American journal of hypertension. 2018;31(11):1205-14.

94. Wu P-H, Yang C-Y, Yao Z-L, Lin W-Z, Wu L-W, Chang C-C. Relationship of blood pressure control and hospitalization risk to medication adherence among patients with hypertension in Taiwan. American journal of hypertension. 2010;23(2):155-60.

95. Chobanian AV, Bakris GL, Black HR, Cushman WC, Green LA, Izzo Jr JL, et al. Seventh report of the joint national committee on prevention, detection, evaluation, and treatment of high blood pressure. Hypertension (Dallas, Tex : 1979). 2003;42(6):1206-52.

96. Almalki ZS, Albassam AA, Alhejji NS, Alotaibi BS, Al-Oqayli LA, Ahmed NJ. Prevalence, risk factors, and management of uncontrolled hypertension among patients with diabetes: A hospital-based cross-sectional study. Primary care diabetes. 2020.

97. Shelley D, Tseng T-Y, Andrews H, Ravenell J, Wu D, Ferrari P, et al. Predictors of blood pressure control among hypertensives in community health centers. American journal of hypertension. 2011;24(12):1318-23.

98. Dua S, Bhuker M, Sharma P, Dhall M, Kapoor S. Body mass index relates to blood pressure among adults. North American journal of medical sciences. 2014;6(2):89.

99. Chorin E, Hassidim A, Hartal M, Havakuk O, Flint N, Ziv-Baran T, et al. Trends in adolescents obesity and the association between $\mathrm{BMI}$ and blood pressure: a cross-sectional study in 714,922 healthy teenagers. American journal of hypertension. 2015;28(9):1157-63.

100. Abebe SM, Berhane Y, Worku A, Getachew A. Prevalence and associated factors of hypertension: a crossectional community based study in Northwest Ethiopia. PloS one. 2015;10(4):e0125210. 
101. Hall JE, Hildebrandt DA, Kuo J. Obesity hypertension: role of leptin and sympathetic nervous system. American journal of hypertension. 2001;14(6 Pt 2):103s-15s.

102. Abate N. Obesity and cardiovascular disease: pathogenetic role of the metabolic syndrome and therapeutic implications. Journal of diabetes and its complications. 2000;14(3):154-74.

103. Wolk R, Shamsuzzaman AS, Somers VK. Obesity, sleep apnea, and hypertension. Hypertension (Dallas, Tex : 1979). 2003;42(6):1067-74.

104. Engeli S, Sharma AM. The renin-angiotensin system and natriuretic peptides in obesity-associated hypertension. Journal of molecular medicine. 2001;79(1):21-9.

\section{Figures}
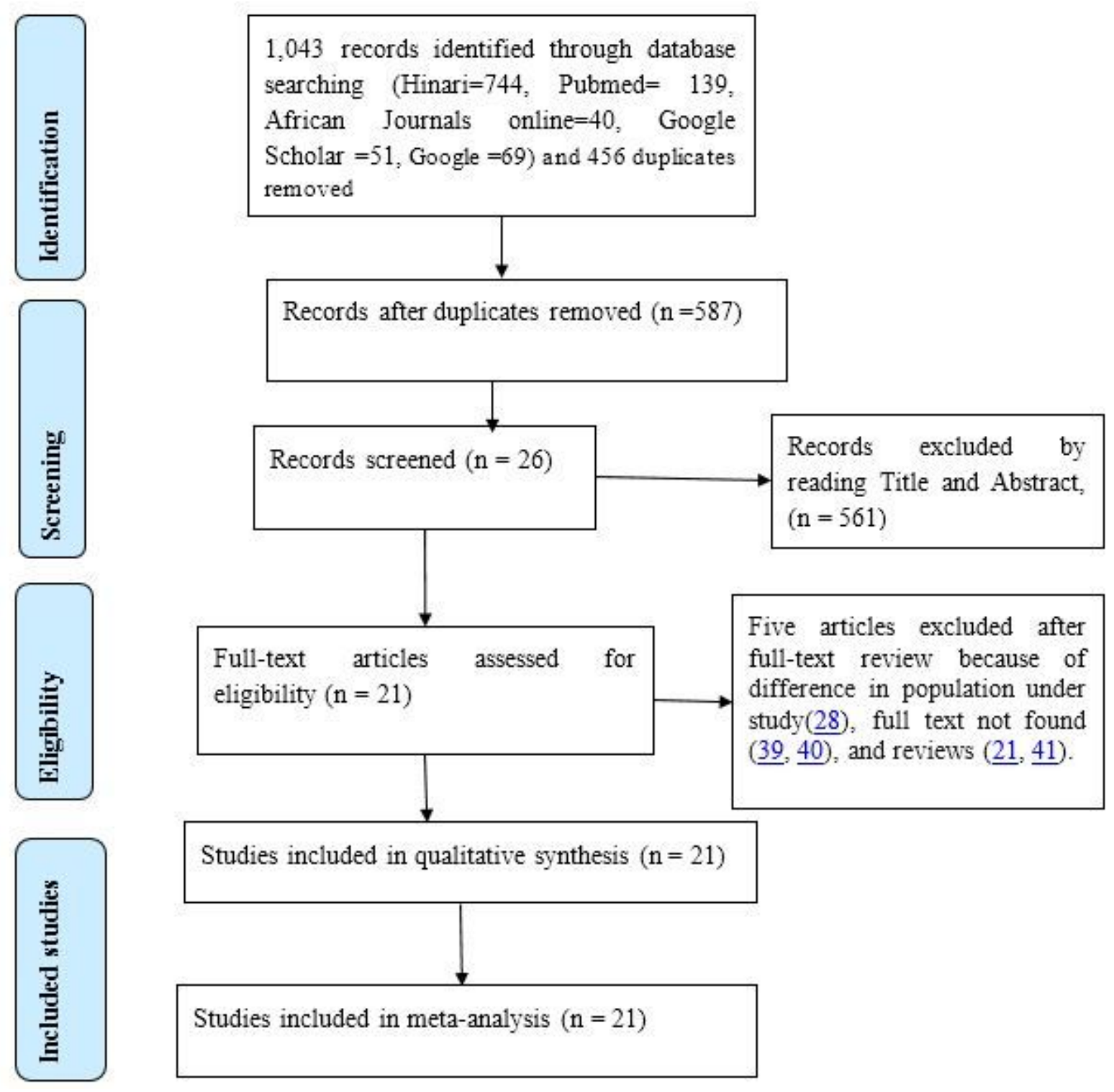

Figure 1 
PRISMA flow diagram for a systematic review and meta-analysis of poor blood pressure control among people living with diabetes in sub-Saharan African countries
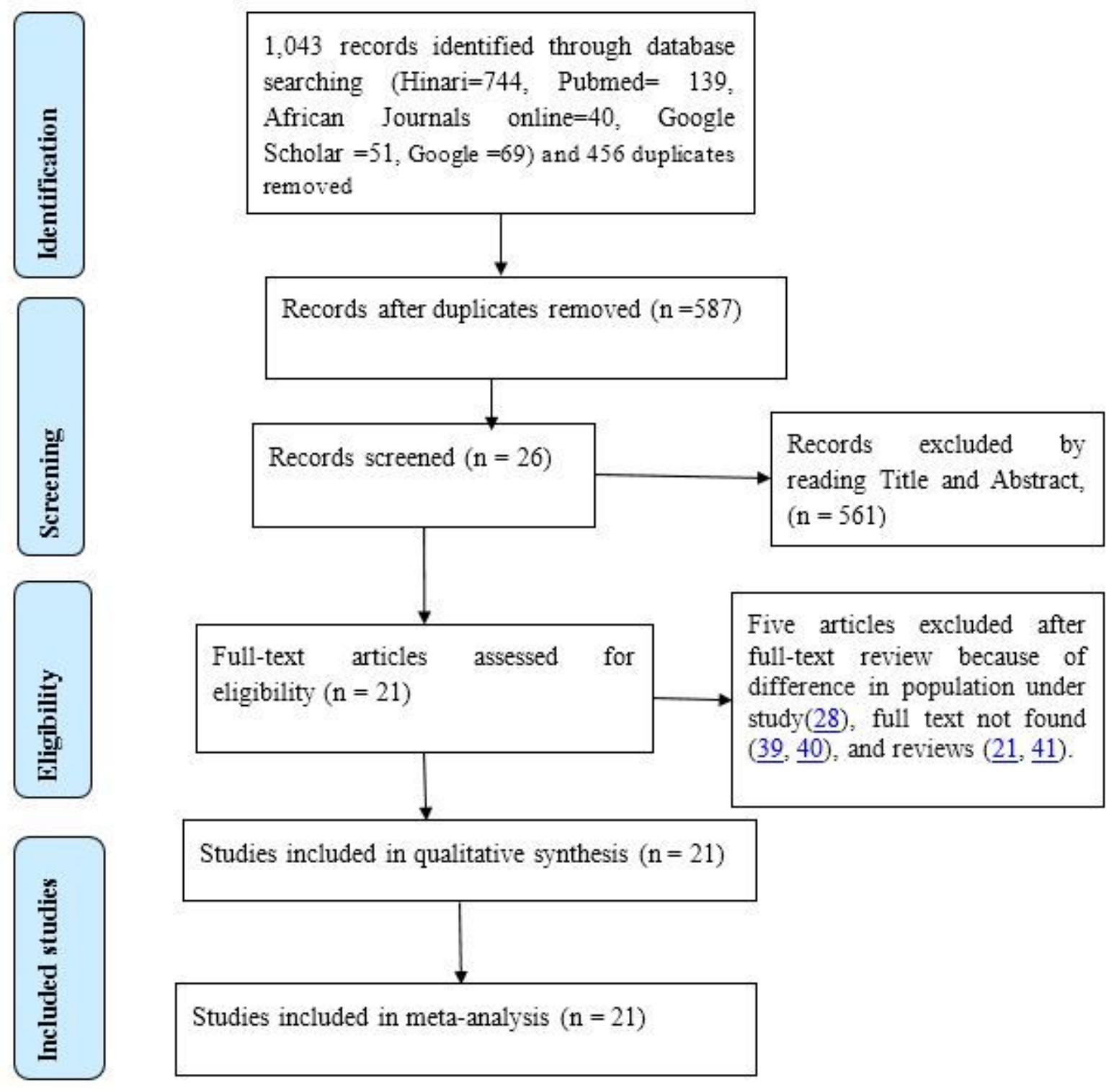

Figure 1

PRISMA flow diagram for a systematic review and meta-analysis of poor blood pressure control among people living with diabetes in sub-Saharan African countries 
N.S. Levitt et al , 1997

E. O. Okoro et al, 2004

Simeon Pierre et.al , 2007

AM Klisiewicz et al, 2009

Mwita JC et al , 2012

Anakwue RC et a, 2012

Y Pinchevsky e al, 2013

B. W. NDEGE et al, 2014

Kibirige et al., 2014

Hailu Abera et al , 2016

Yacob Pinchevsky et al , 2016

Oladele Vincent Adeniyi et al, 2016

Mercy W. Kimando1, 2017

Hailu A et. al. , 2017

Sintayehu Muleta et al, 2017

Semvua B. Kilonzo et al, 2017

James Osei-Yeboah et al, 2018

Tariku Shimels et al, 2018

Emmanuel M Mwengi et al, 2019

Julius Chacha Mwita et al, 2019

Akalu et.al , 2020

\section{Overall}

Heterogeneity: $\mathrm{T}^{2}=217.09, \mathrm{I}^{2}=97.34 \%, \mathrm{H}^{2}=37.64$

Test of $\theta_{1}=\theta_{1} ; \mathrm{Q}(20)=752.88, \mathrm{p}<0.001$

Test of $\theta=0: z=21.35, p<0.001$

61.67 [ 56.16, 67.17] 4.76

89.52 [ $85.38,93.67] \quad 4.83$

82.00 [ $75.85,88.15] \quad 4.72$

$66.00[58.42,73.58] \quad 4.61$

88.10 [ $85.00,91.19] \quad 4.87$

54.20 [ $50.42,57.99] \quad 4.85$

78.90 [ $73.48,84.32] \quad 4.76$

$44.00[37.85,50.15] \quad 4.71$

85.00 [ $81.42,88.58] \quad 4.85$

57.85 [ $51.86,63.85] \quad 4.73$

$75.47[70.29,80.65] \quad 4.78$

76.60 [ $72.37,80.83] \quad 4.83$

63.64 [ $59.35,67.92] \quad 4.82$

56.49 [ $48.00,64.98] \quad 4.54$

84.41 [ $80.27,88.55$ ] 4.83

41.33 [ $33.45,49.21] \quad 4.59$

80.61 [ $76.53,84.69$ ] 4.83

69.20 [ $63.32,75.08$ ] 4.73

45.80 [ $41.43,50.17] \quad 4.82$

74.34 [ 69.94, 78.74] 4.82

69.84 [ $63.43,76.25]$

Random-effects DerSimonian-Laird model

\section{Figure 2}

Forest plot for meta-analysis of poor blood pressure control among DM patients in sub-Saharan Africa countries $(\mathrm{N}=21)$ 
N.S. Levitt et al , 1997

E. O. Okoro et al, 2004

Simeon Pierre et.al , 2007

AM Klisiewicz et al, 2009

Mwita JC et al , 2012

Anakwue RC et a, 2012

Y Pinchevsky e al, 2013

B. W. NDEGE et al, 2014

Kibirige et al., 2014

Hailu Abera et al , 2016

Yacob Pinchevsky et al , 2016

Oladele Vincent Adeniyi et al, 2016

Mercy W. Kimand01, 2017

Hailu A et. al. , 2017

Sintayehu Muleta et al, 2017

Semvua B. Kilonzo et al, 2017

James Osei-Yeboah et al, 2018

Tariku Shimels et al, 2018

Emmanuel M Mwengi et al, 2019

Julius Chacha Mwita et al, 2019

Akalu et.al , 2020

\section{Overall}

Heterogeneity: $\mathrm{T}^{2}=217.09, \mathrm{I}^{2}=97.34 \%, \mathrm{H}^{2}=37.64$

Test of $\theta_{1}=\theta_{1} ; \mathrm{Q}(20)=752.88, p<0.001$

Test of $\theta=0: z=21.35, p<0.001$

Random-effects DerSimonian-Laird model with $95 \% \mathrm{Cl}$

$61.67\left[\begin{array}{llll}56.16,67.17] & 4.76\end{array}\right.$

88.70 [ $82.91,94.48] \quad 4.74$

89.52 [ 85.38, 93.67] 4.83

82.00 [ $75.85,88.15] \quad 4.72$

66.00 [ 58.42, 73.58] 4.61

88.10 [ $85.00,91.19] \quad 4.87$

54.20 [ $50.42,57.99] \quad 4.85$

$78.90[73.48,84.32] \quad 4.76$

44.00 [ $37.85,50.15] \quad 4.71$

85.00 [ $81.42,88.58] \quad 4.85$

$57.85[51.86,63.85] \quad 4.73$

$75.47[70.29,80.65] \quad 4.78$

$76.60[72.37,80.83] \quad 4.83$

63.64 [ $59.35,67.92] \quad 4.82$

56.49 [ $48.00,64.98] \quad 4.54$

84.41 [ $80.27,88.55$ ] 4.83

41.33 [ $33.45,49.21] \quad 4.59$

80.61 [ $76.53,84.69] \quad 4.83$

$69.20[63.32,75.08] \quad 4.73$

$45.80\left[\begin{array}{ll}41.43,50.17] & 4.82\end{array}\right.$

$74.34[69.94,78.74] \quad 4.82$

$69.84[63.43,76.25]$

\section{Figure 2}

Forest plot for meta-analysis of poor blood pressure control among DM patients in sub-Saharan Africa countries $(\mathrm{N}=21)$ 


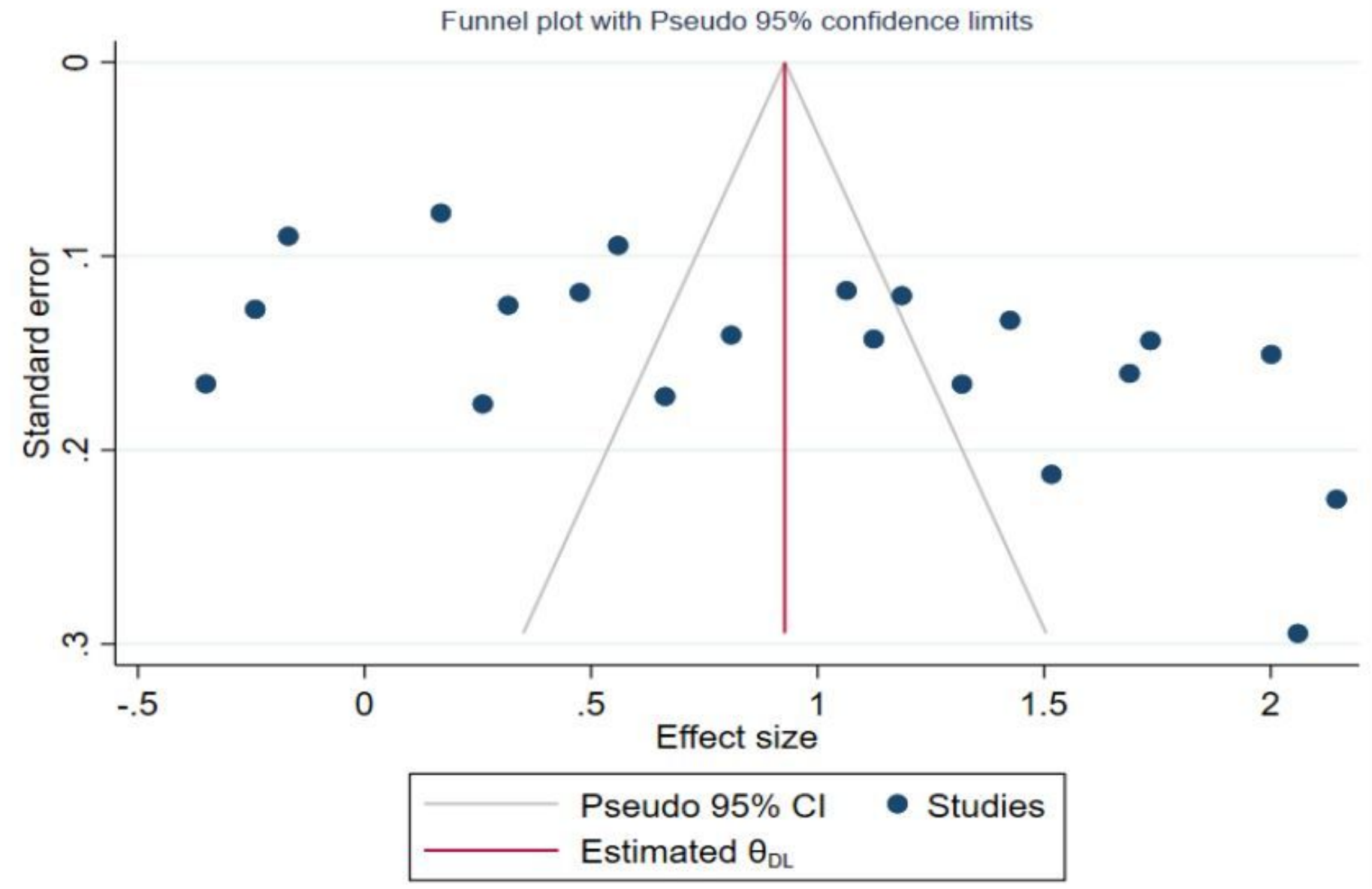

Figure 3

Funnel plot testing publication bias (random, $\mathrm{N}=21$ ) 


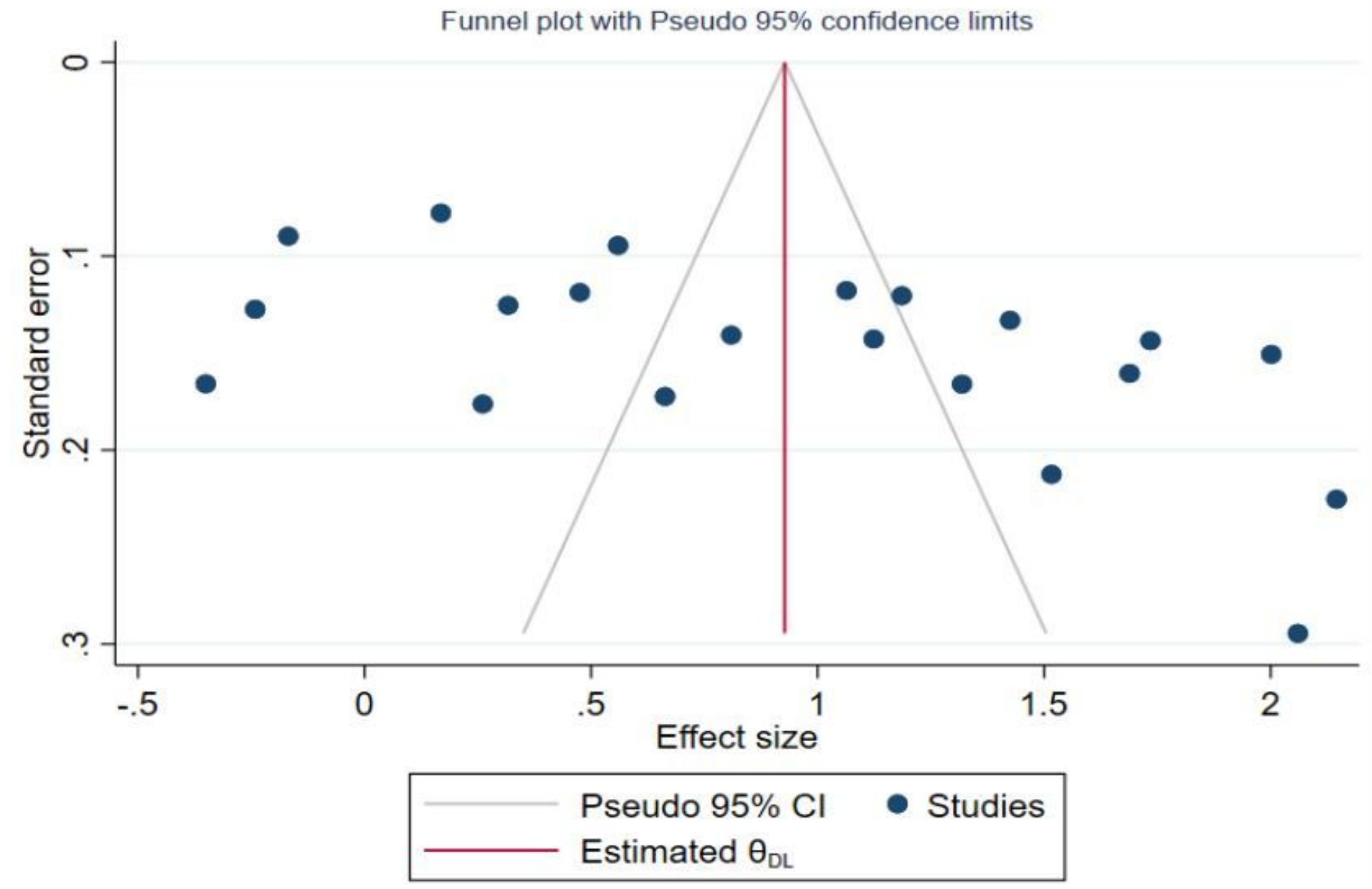

Figure 3

Funnel plot testing publication bias (random, $\mathrm{N}=21$ ) 
Meta-analysis estimates, given named study is omitted | Lower Cl Limit OEstimate | Upper Cl Limit

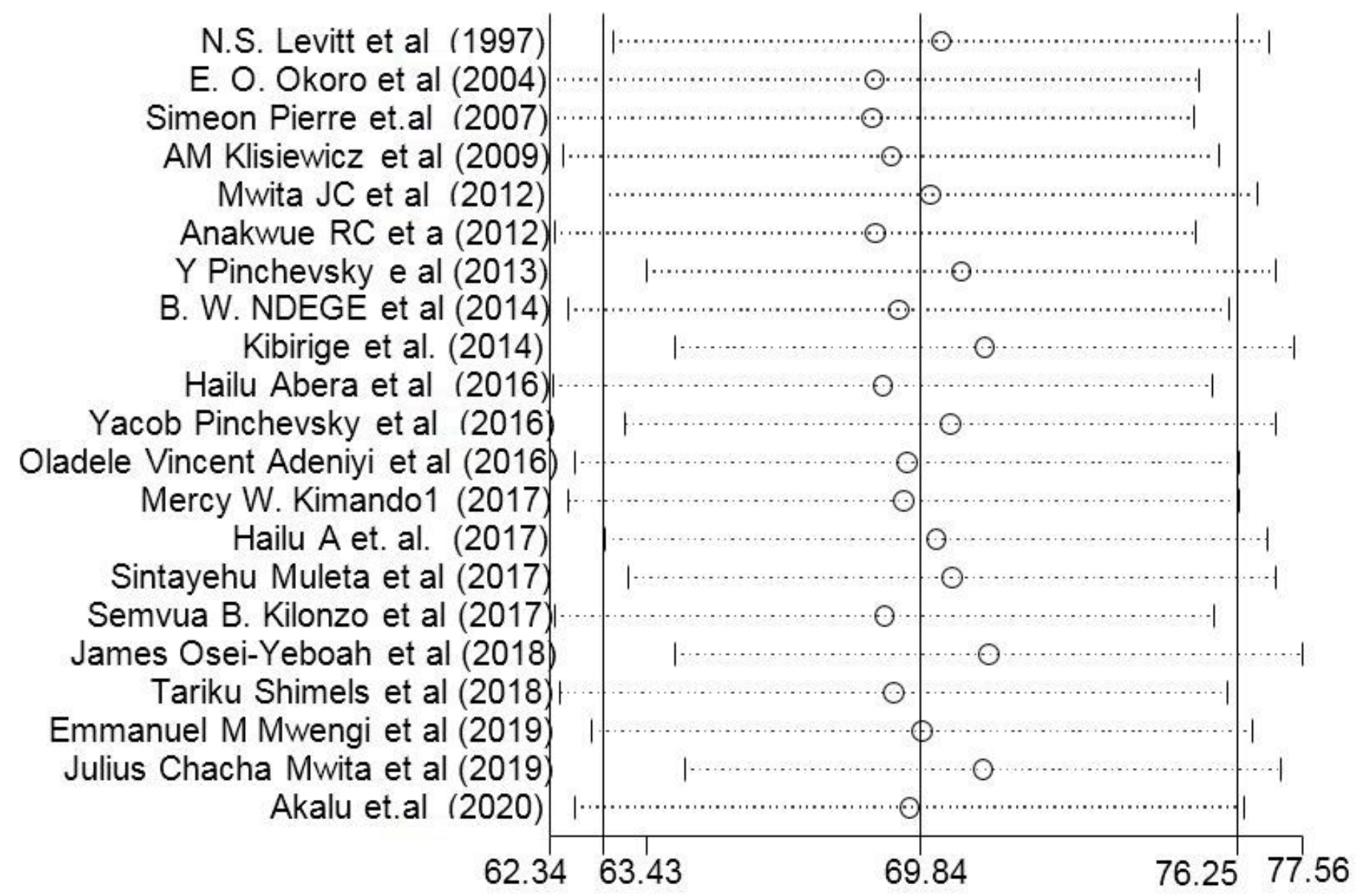

Figure 4

Sensitivity analysis between studies included in a meta-analysis 
Meta-analysis estimates, given named study is omitted | Lower Cl Limit OEstimate | Upper Cl Limit

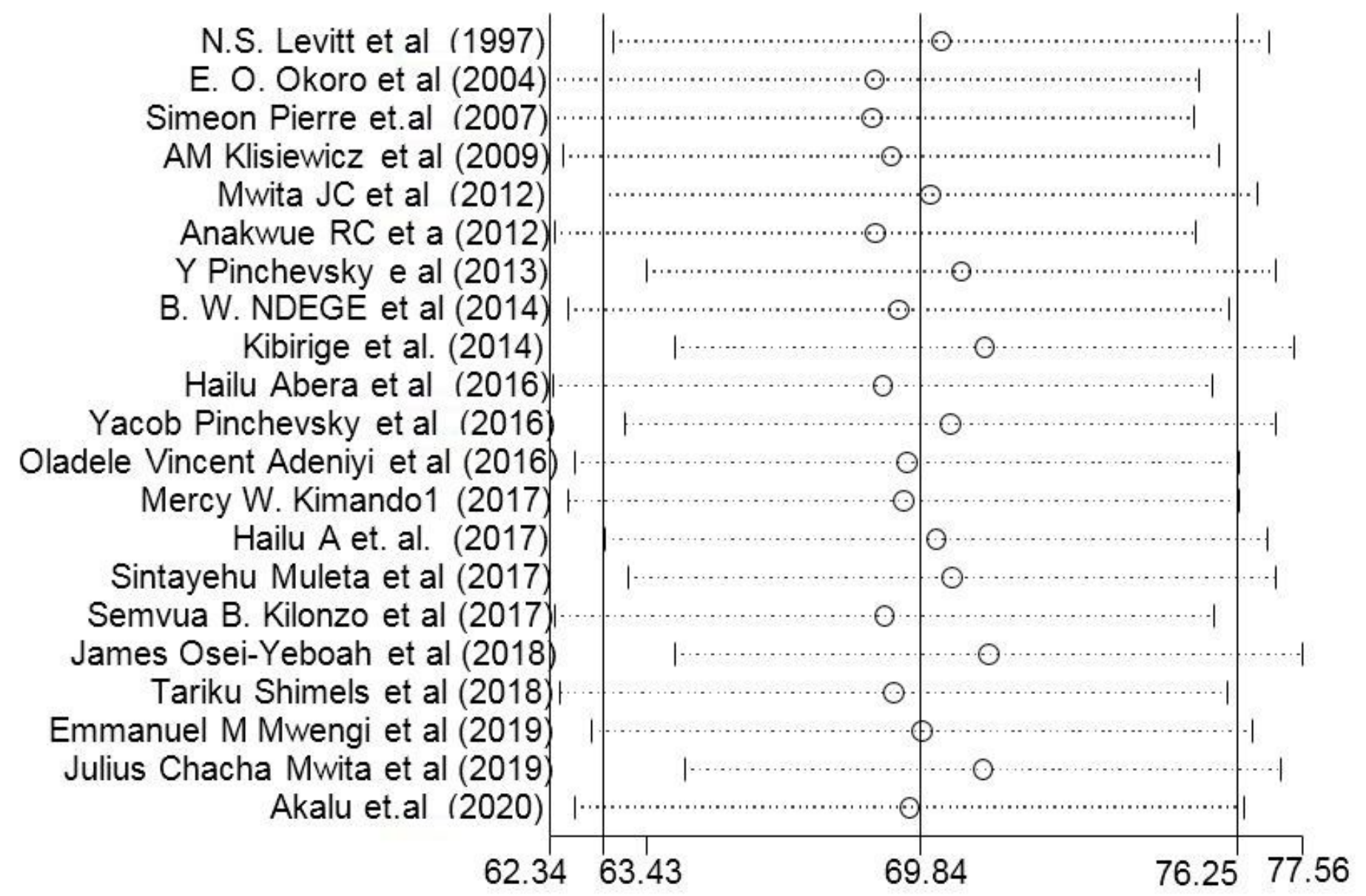

Figure 4

Sensitivity analysis between studies included in a meta-analysis

Study(Author, Year)

POR

with $95 \% \mathrm{Cl}$

Weight

Oladele Vincent Adeniyi et al, 2016

Sintayehu Muleta et al, 2017

Semvua B. Kilonzo et al, 2017

Tariku Shimels et al, 2018

\section{Overall}

Heterogeneity: $\mathrm{T}^{2}=0.00, \mathrm{I}^{2}=0.00 \%, \mathrm{H}^{2}=1.00$

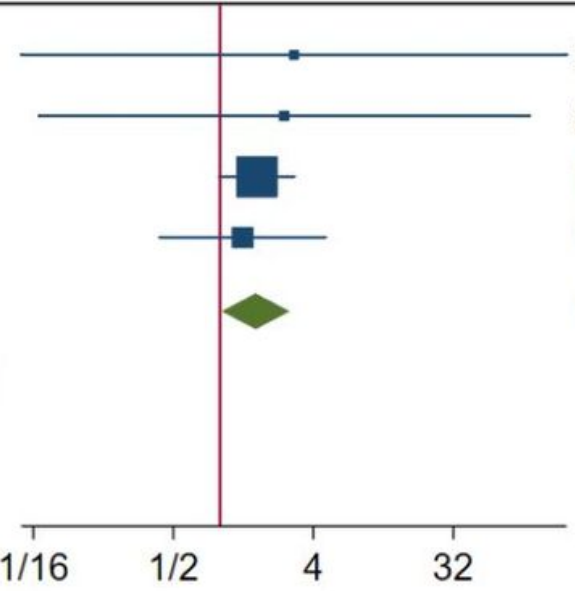

3.00 [ $0.05,172.18]$

1.53

$2.60[0.07,99.03] \quad 1.90$

$1.73[0.99, \quad 3.03] 80.10$

$1.40[0.41,4.81] 16.47$

$1.70\left[\begin{array}{ll}1.03, & 2.80\end{array}\right]$

Test of $\theta_{\mathrm{i}}=\theta_{\mathrm{j}}: \mathrm{Q}(3)=0.23, p=0.97$

Test of $\theta=0: z=2.07, p=0.04$

Random-effects DerSimonian-Laird model

Figure 5 
Forest plot for the association between poor adherence to antihypertensive drugs and poor blood pressure control among diabetic peoples in sub-Saharan countries

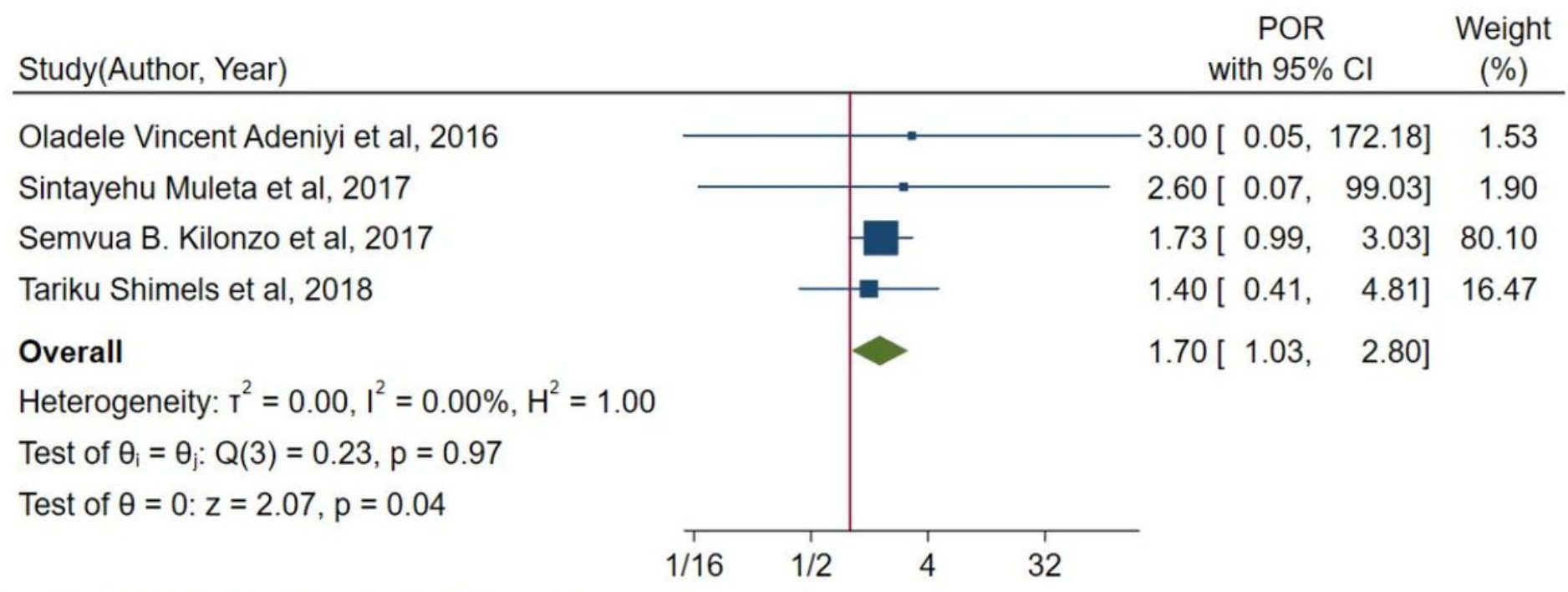

Random-effects DerSimonian-Laird model

Figure 5

Forest plot for the association between poor adherence to antihypertensive drugs and poor blood pressure control among diabetic peoples in sub-Saharan countries

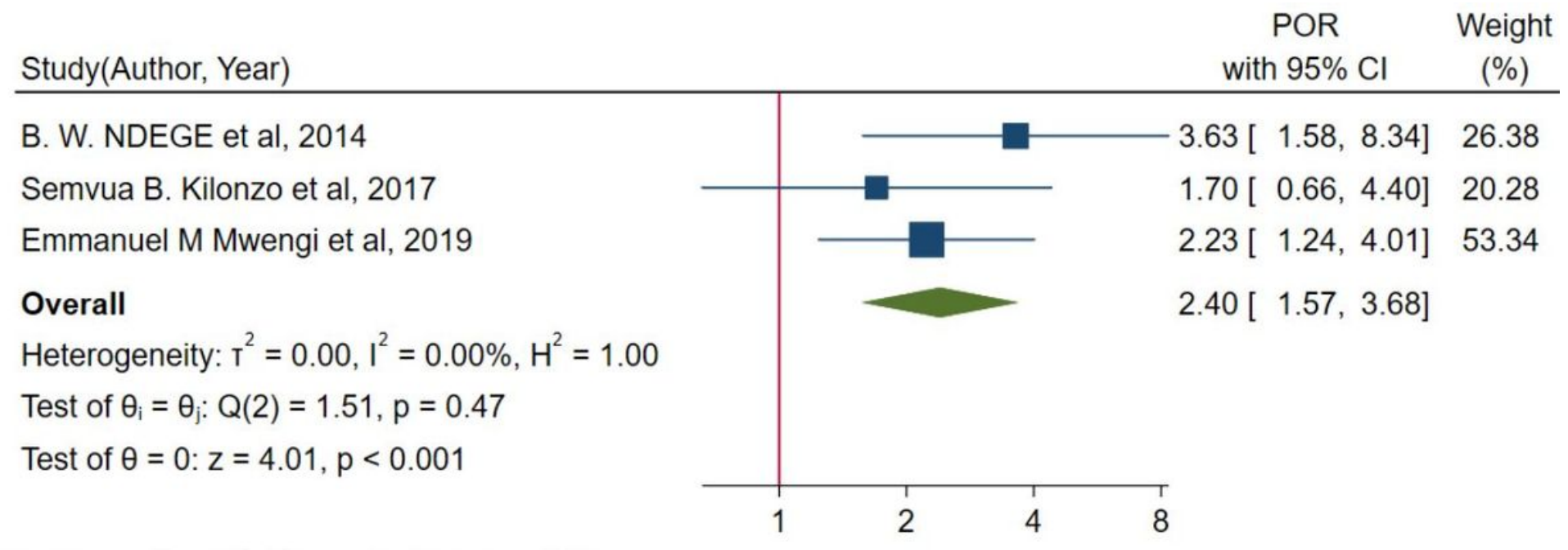

Random-effects DerSimonian-Laird model

\section{Figure 6}

Forest plot for the association between BMI and poor blood pressure control among diabetic peoples in sub-Saharan countries. 
B. W. NDEGE et al, 2014

Semvua B. Kilonzo et al, 2017

Emmanuel M Mwengi et al, 2019

Overall

Heterogeneity: $T^{2}=0.00, I^{2}=0.00 \%, H^{2}=1.00$

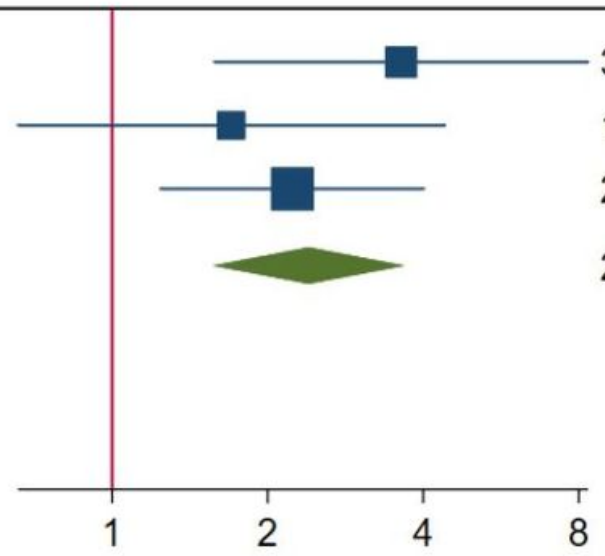

3.63 [ $1.58,8.34] 26.38$

$1.70[0.66,4.40] 20.28$

2.23 [ $1.24,4.01] 53.34$

$2.40[1.57,3.68]$

Test of $\theta_{\mathrm{i}}=\theta_{\mathrm{j}}: \mathrm{Q}(2)=1.51, \mathrm{p}=0.47$

Test of $\theta=0: z=4.01, p<0.001$

Random-effects DerSimonian-Laird model

Figure 6

Forest plot for the association between $\mathrm{BMI}$ and poor blood pressure control among diabetic peoples in sub-Saharan countries.

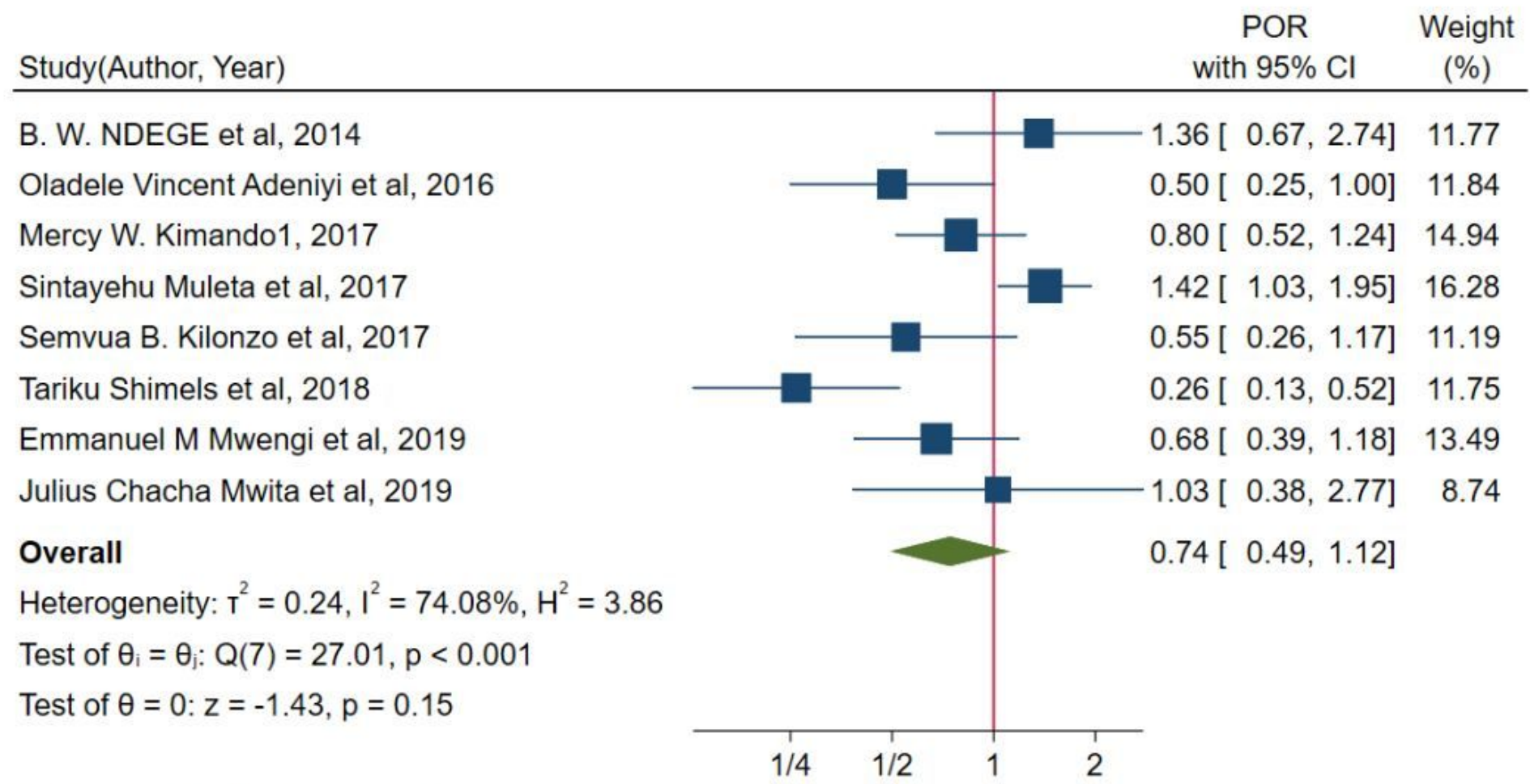

Random-effects DerSimonian-Laird model

Figure 7

Forest plot for the association between sex (being female) and poor blood pressure control among diabetic peoples in sub-Saharan countries. 
B. W. NDEGE et al, 2014

Oladele Vincent Adeniyi et al, 2016

Mercy W. Kimando1, 2017

Sintayehu Muleta et al, 2017

Semvua B. Kilonzo et al, 2017

Tariku Shimels et al, 2018

Emmanuel M Mwengi et al, 2019

Julius Chacha Mwita et al, 2019

Overall

Heterogeneity: $\mathrm{T}^{2}=0.24, \mathrm{I}^{2}=74.08 \%, \mathrm{H}^{2}=3.86$

Test of $\theta_{\mathrm{i}}=\theta_{\mathrm{j}}: \mathrm{Q}(7)=27.01, \mathrm{p}<0.001$

Test of $\theta=0: z=-1.43, p=0.15$

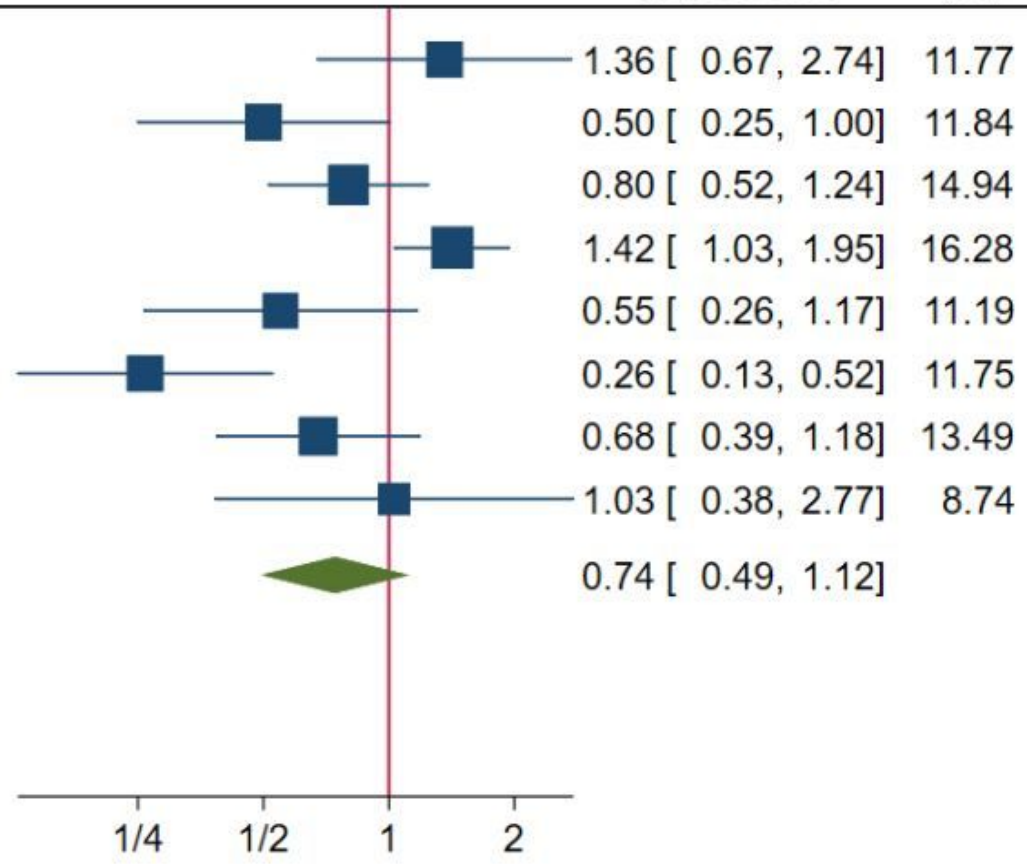

Random-effects DerSimonian-Laird model

\section{Figure 7}

Forest plot for the association between sex (being female) and poor blood pressure control among diabetic peoples in sub-Saharan countries.

\section{Supplementary Files}

This is a list of supplementary files associated with this preprint. Click to download.

- 3.Supplementaryfigures.docx

- 3.Supplementaryfigures.docx

- 4.Searchstrategiesofdifferentdatabases.docx

- 4.Searchstrategiesofdifferentdatabases.docx

- S1TablePRISMAPchecklistPoorBPcontrol.docx

- S1TablePRISMAPchecklistPoorBPcontrol.docx 